Portland State University

PDXScholar

\title{
Workplace Cognitive Failure as a Mediator between Work-Family Conflict and Safety Performance
}

\author{
Rachel Jane Daniels \\ Portland State University
}

Follow this and additional works at: https://pdxscholar.library.pdx.edu/open_access_etds

Part of the Industrial and Organizational Psychology Commons, and the Personality and Social Contexts Commons

Let us know how access to this document benefits you.

\section{Recommended Citation}

Daniels, Rachel Jane, "Workplace Cognitive Failure as a Mediator between Work-Family Conflict and Safety Performance" (2007). Dissertations and Theses. Paper 1674.

https://doi.org/10.15760/etd.1673

This Thesis is brought to you for free and open access. It has been accepted for inclusion in Dissertations and Theses by an authorized administrator of PDXScholar. Please contact us if we can make this document more accessible: pdxscholar@pdx.edu. 


\section{THESIS APPROVAL}

The abstract and thesis of Rachel J. Daniels for the Master of Science in Applied

Psychology were presented on August 10, 2007, and accepted by the thesis committee and the department.

COMMITTEE APPROVALS:

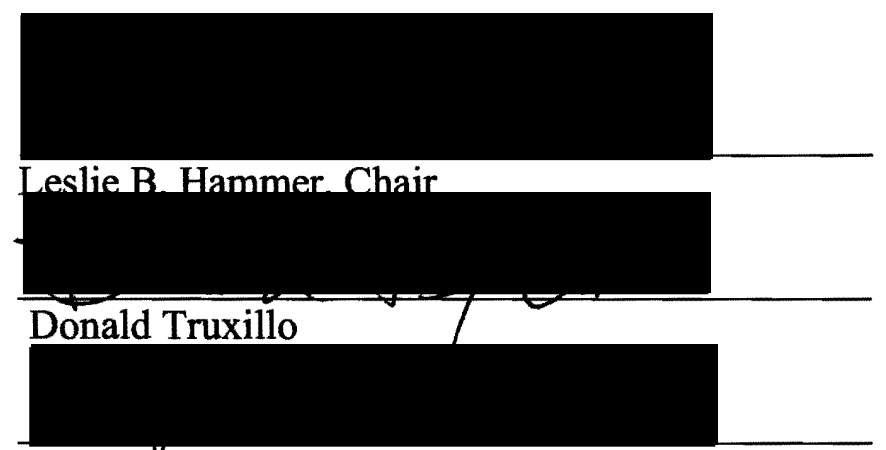

Cynthid Mohr

DEPARTMENT APPROVAL:

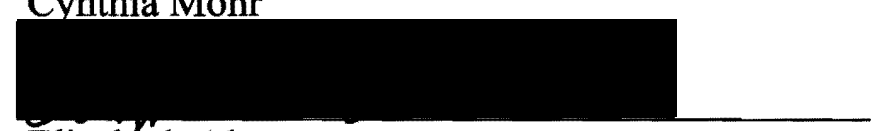

Elizableth Almer

Repuesentative of the Office of Graduate Studies

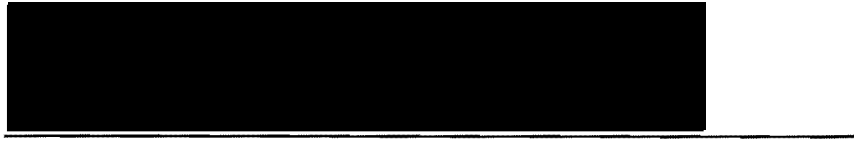

Keith Kauffman, Chair

Department of Psychology 


\begin{abstract}
An abstract of the thesis of Rachel J. Daniels for the Master of Science in Applied Psychology presented August, 10, 2007.
\end{abstract}

Title: Workplace Cognitive Failure as a Mediator between Work-Family Conflict and Safety Performance

The main goal of this thesis was to examine the effects of family-to-work conflict on safety performance. Data were collected from a sample of 134 employees, consisting primarily of construction workers. Results found that levels of conflict from the family role to the work role negatively affected participants' workplace cognitive failure, or cognitively based errors that occur during the performance of a task that the person is normally successful in executing. Workplace cognitive failure, in turn, was a significant predictor of levels of safety performance, both employees' compliance with safety procedures and the extent to which they participated in discretionary safety-related activities. Although family-to-work conflict did not significantly predict levels of safety performance, results suggest that it is a practical antecedent of workplace cognitive failure, which is an important predictor of safety behaviors. Future research should explore further antecedents to workplace cognitive failure. 
WORKPLACE COGNITIVE FAILURE AS A MEDIATOR BETWEEN WORK-

FAMILY CONFLICT AND SAFETY PERFORMANCE

by

RACHEL J. DANIELS

A thesis submitted in partial fulfillment of the requirements for the degree of

\section{MASTER OF SCIENCE \\ in \\ PSYCHOLOGY}

Portland State University

2007 


\section{TABLE OF CONTENTS}

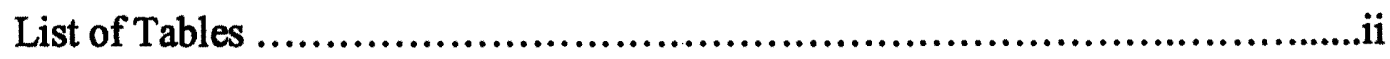

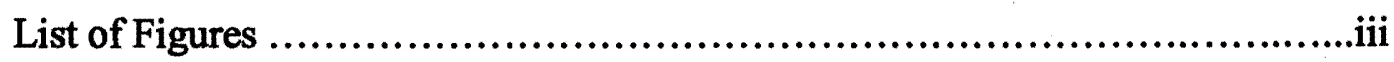

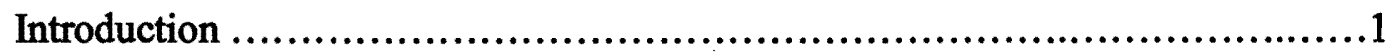

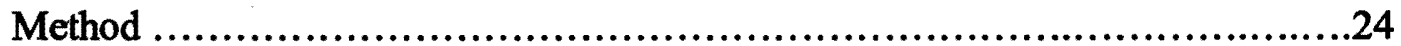

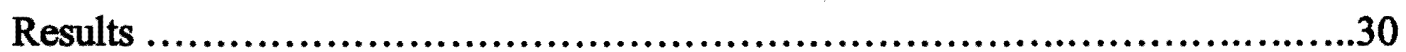

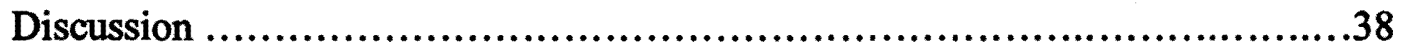

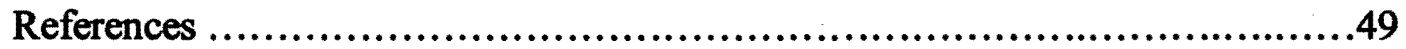

Appendix A: Focus Group Process ............................................61

Appendix B: Informed Consent- Focus Group ..................................62

Appendix C: Focus Group Demographics ...................................63

Appendix D: Focus Group Questions ......................................64

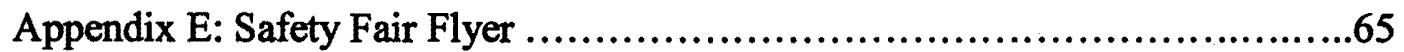

Appendix F: Informed Consent- Survey ...................................66

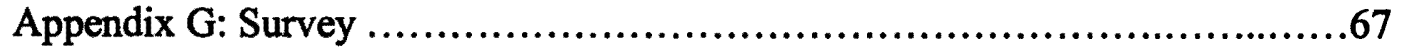




\section{LIST OF TABLES}

Table 1: Means and Standard Deviations for Demographics........................78

Table 2: Frequencies for Categorical Demographics.............................79

Table 3: Intercorrelations between Study Variables................................81

Table 4: Summary of Regression Analysis for Testing Hypothesis 4a............82

Table 5: Summary of Regression Analysis for Testing Hypothesis 4b...........83

Table 6: Summary of Hierarchical Regression Analysis for Testing

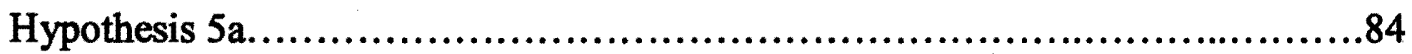

Table 7: Summary of Hierarchical Regression Analysis for Testing

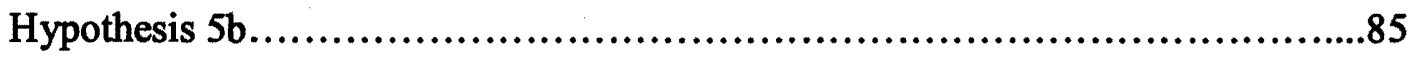

Table 8: Summary of Regression Analysis for Testing Post Hoc Analyses...........86

Table 9: Summary of Regression Analysis for Testing Post Hoc Analyses..........87 


\section{LIST OF FIGURES}

Figure 1. Theoretical framework for the Relationships between Family-to-Work Conflict, Workplace Cognitive Failure, Safety Performance and Safety

Climate..................................................................... 88 


\section{INTRODUCTION}

A significant problem for organizations today is safety in the workplace. Industrial accidents cost the United States economy an estimated $\$ 156.2$ billion per year, which amounts to $\$ 1,120$ per worker (National Safety Council, 2003). On the job, 3.4 million workers suffered disabling injuries in one year (National Safety Council, 2003). To understand the social significance of these injuries, the total cost for occupational injuries and illnesses to the US economy was estimated to be $\$ 149$ billion in 1992, which is five times the costs associated with AIDS and comparable to the total costs for cancer (Krause \& Lund, 2004). Workplace injuries often result in a loss of income, decreased involvement in family activities, increased family strain, and medical costs not covered by workers' compensation plans (Dembe, 2001). Of particular importance to this study, the construction industry has been plagued by more workplace injuries than most occupations and has a higher death rate than other occupations (BLS, 2004). The construction industry reported 1,224 injuries in 2004, which was an eight percent increase from the previous year.

Understanding the factors that contribute to such injuries is an important area for future research. The field of psychology has provided a way to further examine such causes beyond traditional hazards examined in the Occupational Safety and Health field. One such factor identified as being related to safety on the job is work-family conflict (Cullen \& Hammer, 2007). Thus, including 
work-family factors as potential hazards in Occupational Safety and Health research is a useful strategy.

In recent years, numerous changes have come about in employee and family roles, along with changes in the relationship between these work and family domains. For one example, in $2000,61 \%$ of all married women over age 16 were in the workforce, compared to just $41 \%$ in 1970 (US Census Bureau, 2001). Other examples of changes include the increasing percentage of families supported by dual incomes, increases in single parents in the workforce, and greater gender integration into organizations (Hammer, Colton, Caubet, \& Brockwood, 2002). For example, one-fifth of all workers with children under 18 are single parents, and $40 \%$ of households are comprised of dual earner parents (Bianchi \& Raley, 2005). In 2002, 78\% of working couples were dual-earner and $22 \%$ single-earner, compared with $66 \%$ and 34\%, respectively, in 1997 (Bond, Thompson, Galinsky, \& Prottas, 2003). Along with these changes, there has been a corresponding increased need for people to manage work and family demands.

Despite agreement that work-family conflict has negative effects on employees, families of employees, and employers, only one published study has addressed how stress from conflicting work and family roles might affect safety behaviors at work (Cullen \& Hammer, 2007). The main purpose of the present study was to investigate how the stress resulting from work-family conflict affects workplace safety performance. Cullen and Hammer argued that having 
conflicting work and family demands may result in employees having less time and energy for volunteering to participate in activities designed to increase employee awareness of workplace safety. Moreover, the authors assert that in times of work-family conflict, this stress may affect the employees' attention to safety rules and procedures, resulting in unintentional noncompliance with safety protocols. In a sample of 243 health care workers, results from Cullen and Hammer (2007) showed that increased family-to-work conflict, specifically, was associated with decreased compliance with safety rules and less willingness to participate in discretionary safety meetings, primarily through decreased safety motivation. The present study extends this research to a different population (construction workers), and makes contributions above and beyond the results from the Cullen and Hammer study by attempting to better understand the psychological mechanisms underlying the relationship between work-family conflict and safety.

The main goal of this thesis was to examine the effects of work-family conflict on safety performance among a sample consisting primarily of construction workers. It is expected that high levels of conflict between work and family roles will negatively affect both employees' compliance with safety procedures, and the extent to which they participate in discretionary safetyrelated activities. More specifically, based on results from Cullen and Hammer (2007), it was hypothesized that conflict from the family role to the work role will negatively affect safety performance. It was further hypothesized that 
cognitively based errors that occur during the performance of a task that the person is normally successful in executing, or workplace cognitive failure, accounts for the relationship between family-to-work conflict and both safety compliance and participation. In other words, workplace cognitive failure mediates the negative effects of family-to-work conflict on safety compliance and safety participation behaviors. Further, it was hypothesized that safety climate moderates this relationship between workplace cognitive failure and safety participation and compliance (see Figure 1).

\section{Work-Family Conflict}

When discussing work-family conflict, it is beneficial to first define the concepts involved. Work-family conflict can be defined as "a form of interrole conflict in which the role pressures from work and family domains are mutually incompatible in some respect" (Greenhaus \& Beutell, 1985, p. 77). Greenhaus and Beutell (1985) go on to say that participation in the work role is made more difficult by virtue of participation in the family role, and vice versa.

Work-family conflict was first conceptualized as a unidimensional construct, but is now studied as two distinct facets: work-to-family and familyto-work conflict (Eby et al., 2005). Work-to-family conflict presents itself when work interferes with family. In family-to-work conflict, family interferes with work (Frone, Russel, \& Cooper, 1992). Frone et al. (1992) developed a model of the work-family interface which specifically distinguished between work interfering with family and family interfering with work. This study supported 
the idea that the conflict relationship between work and family is bidirectional or reciprocal; and demonstrated the unique antecedents of each type of workfamily conflict (Frone et al., 1992). It was found that job stressors and job involvement were both positively related to the frequency of work-to-family conflict. Family stressors and family involvement were positively related to the frequency of family-to-work conflict. Results from Golden, Veiga and Simsek (2006) found further support for the bidirectional nature of work-family conflict. The authors studied a group of telecommuters employed at a high-tech firm. Results found that the more extensively individuals telecommute, the less that work interferes with family, but the more that family interferes with work. Job autonomy and schedule flexibility were moderators in this relationship between telecommuting and work-family conflict. These results support the differential impact of telecommuting on work-to-family conflict and family-to-work conflict.

Antecedents of work-family conflict include job stressors, family stressors, job involvement, and family involvement (Frone et al., 1992; Greenhaus \& Beautell, 1985). In the work domain specifically, antecedents that have been shown to predict work-to-family conflict include workload (Major, Klein, \& Ehrhart, 2002), job role quality (Barnett, Marshall, Raudenbush, \& Brennan, 1993), supervisor and coworker support (Frone, Yardley, \& Markel, 1997), and perceived flexibility (Hammer, Allen, \& Grigsby, 1997). In the family domain, characteristics related to family-to-work conflict include stress 
from being a parent or spouse (Frone et al., 1992), elder care demands (Gibeau \& Anastas, 1989), spousal and family support (Frone et al., 1997), and satisfaction with child care arrangements (Goff, Mount, \& Jamison, 1990).

The consequences of conflicting work and family roles are particularly relevant to the present study. Researchers have demonstrated how experiences of work-family conflict can result in many outcomes at home, at work, and for the individual in general. Affecting the home domain, work-family conflict has been shown to have a negative impact on family performance (e.g., Frone et al., 1997), marital well-being (e.g., MacEwen \& Barling, 1994) and family wellbeing (e.g., Parasuraman, Greenhaus, \& Granrose, 1992), as well as cause family distress (e.g., Frone et al., 1992). Regarding the workplace, research has shown work-family conflict to have a negative impact on work performance (e.g., Frone et al., 1997), organizational commitment and job satisfaction (e.g., Good, Sisler, \& Gentry, 1988; Netemeyer et al., 1996) and is positively related to work distress (Frone et al., 1992), absenteeism (e.g., Hammer, Bauer, \& Grandey, 2003) and burnout (e.g., Burke, 1994). Affecting the individual in particular, work-family conflict has been negatively related to emotional well being (e.g., Burke, 1988; Hammer, Cullen, Neal, Sinclair, \& Shafiro, 2005; Richardsen, Burke, \& Mikkelsen, 1999) and life satisfaction (e.g., Duxbury \& Higgins, 1991; Greenhaus, Parasuraman, Rabinowitz, Bedian, \& Mossholder, 1989; Richardsen et al., 1999), and has been positively related to psychological strain (e.g., Barling, MacEwen, Kelloway, \& Higginbottom, 1994), alcohol 
abuse (e.g., Frone, 2000; Frone et al., 1993), and depression (e.g., Frone, 2000;

Frone, Russell, \& Cooper, 1991; Hammer et al., 2005; Kinnunen \& Mauno, 1998; Major et al., 2002; Stephens et al., 1997).

Researchers in the area of work-family conflict have focused on delineating family-related, job-related and individual-focused consequences of work-family conflict, but have largely ignored safety as a potential outcome. One notable exception is the study conducted by Cullen and Hammer (2007), in which the researchers found that increased family-to-work conflict was associated with decreased compliance with safety rules and less willingness to participate in discretionary safety meetings, primarily through decreased safety motivation. Results from this study found that family-to-work conflict was related to safety compliance and safety participation by way of reducing participants' safety motivation. The authors suggested that the reason this relationship did not exist with work-to-family conflict because of the outcomes examined. Since work-to-family conflict involves the work role interfering with the family role, it is logical that it does not have the same effect on work outcomes that family-to-work conflict has. The proposed study argues for a similar differentiation as in Golden et al. (2006). Being that safety performance is a work outcome, it is hypothesized that the family role interfering with the work role (family-to-work conflict) will have a significant relationship with safety performance, while work-to-family conflict will not. 
Summing up the previous research, studies have demonstrated a variety of negative, but differential, effects that work-family conflict can have on individual, family, and work outcomes. Given these negative consequences, employers should be concerned about their employees' family responsibilities not just because of the detrimental effects stress can have on employees, but also because of the economic costs associated with the decreased productivity. Furthermore, employers should take action to alleviate work-family conflict for their employees because of the potential detrimental effects on workplace safety. Workplace Cognitive Failure

For years researchers have recognized the potential negative effects of stress on performance (e.g., Hobfoll, 1989; Karasek, 1979; Lazarus, 1966). These negative effects include billions of dollars of lost income, lost workdays, and decreased quality of performance (Hobfoll \& Shirom, 2001). The general assumption is that individuals have finite cognitive resources, and that prolonged exposure to stressors can increase the demands on these limited cognitive resources (Fried, Ben-David, Tiegs, Avital, \& Yeverechyahu, 1998). When experiencing stress, employees have fewer cognitive resources available for monitoring and performing the behaviors necessary to perform job duties and responsibilities (e.g., Cohen, 1980; Fried et al., 1998). As an illustration of the connection between stress and performance, Fried et al. (1998), studying a population of blue-collar employees in Israel, found that increases in individual 
role stressors were associated with lower levels of supervisor-rated job performance.

Hobfoll's (1989) model of conservation of resources proposes that people strive to retain, protect, and build resources, and further, what threatens them is potential or actual loss of the resources. This model considers resources as the single unit necessary for understanding stress, and defines resources as valued objects, personal characteristics, conditions or energies, or a means for obtaining them. Stress is then thought of as either a threat to or an actual loss of resources, or a lack of resource gain following an investment of resources. When individuals are confronted with stress, the model predicts individuals will strive to minimize the net loss of resources. Hobfoll and Shirom (2001, p. 57) went on to assert that "one major source of stress is the interface between work and home demands," suggesting that work-family conflict is a potential threat to employees cognitive resources. If employees are experiencing stress from conflicting work and family roles, there may be a negative impact on job performance. The present study evaluates whether this effect also extends to safety performance.

Research has suggested that safety performance is related to cognitive failure. A study by Wallace and Vodanovich (2003a) found cognitive failure to be related to safety behavior and workplace accidents, even when controlling for age, gender, experience and conscientiousness. Cognitive failure is defined as a "cognitively based error that occurs during the performance of a task that the 
person is normally successful in executing" (Martin, 1983, p. 97).The researchers found that cognitive failure is a moderator in the relationship between conscientiousness and unsafe work behaviors and accidents, in that the negative relationship between conscientiousness and unsafe work behaviors and accidents will be stronger at higher levels of cognitive failure than at lower levels. It was also found that cognitive failure uniquely accounted for workplace safety behavior and accidents over and above conscientiousness.

Wallace and Vodanovich (2003b) found that cognitive failure significantly predicted automobile accidents, along with work accidents. Utilizing a sample of electrical workers, the authors collected both self-report safety data and safety data obtained from supervisors and organizational records. Similarly, Larson, Alderton, Neideffer and Underhill (1997) found a link between high cognitive failure scores and accidents. Studying a population of American Navy recruits, accidents were measured by a composite score comprising of accident citations, injury-caused hospitalizations, and serious falls. A significant relationship was found between this composite of mishaps, labeled accidents, and a score on a cognitive failure questionnaire.

Wallace and Chen (2005) developed a measure of workplace cognitive failure, and they state that "negative relationships exist between workplace cognitive failure, and safety-related behaviors and outcomes (p. 619)." Wallace and Chen (2005) assert that workplace cognitive failure predicts safety behavior to a greater extent than trait cognitive failure, since it specifically includes the 
regulatory skills that account for work behavior. Trait cognitive failure assesses one's proneness in everyday common life for committing failures in perception, memory and motor function (Broadbent, Cooper, Fitzgerald, \& Parkes, 1982). To develop the measure of workplace cognitive failure, Wallace and Chen (2005) integrated motivational theories of self-regulation with research on safety in the workplace. Three components were conceptualized to comprise the construct of workplace cognitive failure: memory (e.g., information retrieval failures), attention (e.g., failures in perception) and action (e.g., performance of unintended actions). In Study 1, full-time employees from a variety of occupations were first administered a 22-item version of the Workplace cognitive failure scale. Four hierarchical regressions were conducted to assess the utility of the Workplace Cognitive Failure Scale (WCFS) over and above the trait-like version in predicting supervisor safety ratings, injuries, missed days and restricted work days. Workplace cognitive failure accounted for additional variance in all four criteria over and above general cognitive failure. Next, a sample of both military and production employees was used to replicate Study 1 . A shortened version of the WCFS was utilized in Study 2, and safety outcomes included supervisor-provided measures of safety compliance (for the military sample) and accident data that included the number of injuries, days off due to injury and the number of restricted work days due to injury over a two year time span (production employees). The factorial validity of this scale was tested via confirmatory factor analysis. The results of the study supported the validity and 
utility of the new measure of workplace cognitive failure in assessing safety behavior and outcomes in organizations. Although different safety-related outcomes were used in Wallace and Chen (2005) than the present study, the results suggest that safety performance (safety compliance and participation) will be an outcome of workplace cognitive failure.

As further support, this idea was expressed in the study by Cullen and Hammer (2007), which suggested that work-family conflict places additional demands on workers' limited cognitive resources, reducing levels of safety compliance and participation.

\section{Safety Performance}

Safety performance is an aspect of safety that plays an important role in organizations (Neal \& Griffin, 2004). The model of safety performance used by Griffin and Neal (2000) helps in examining the effects of work-family conflict on safety performance behaviors. Based on the two major components of job performance, Griffin and Neal (2000) divided safety performance into two dimensions. The two major components of job performance are task performance, which refers to formal role-prescribed duties, and contextual performance, which is informal non-role-prescribed activities, but contributes to the broader organizational, social and psychological environment (Borman \& Motowidlo, 1993). Based on definitions of task performance, Griffin and Neal defined safety compliance as "the core safety activities that need to be carried out by individuals to maintain workplace safety" (p. 349). Safety compliance 
includes behaviors such as following correct procedures, obeying safety regulations and using appropriate equipment (Neal \& Griffin, 2004). Examples of safety compliance include wearing personal protective equipment when required and abiding by safety regulations and procedures.

The second component of safety performance is participation. Based on definitions of contextual performance, Griffin and Neal (2000, p. 349) defined safety participation as "behaviors such as participating in voluntary safety activities or attending safety meetings." Safety participation includes behavior that does not directly contribute to an individual employee's safety, but contributes to the safety of the wider organization (Neal \& Griffin, 2004). Examples of safety participation include helping coworkers and communicating to coworkers when witnessing unintentional incidents of safety noncompliance. Safety compliance and participation have been referred to as safety behaviors that reflect not only the safety requirements, but also the non-prescribed safety activities that contribute to an organization's overall safety environment (Griffin \& Neal, 2000).

Another safety performance framework is that offered by Burke, Sarpy, Tesluk, and Smith-Crowe (2002) in a study of hazardous waste workers. A confirmatory factor analytic test of a model of general safety performance provided support for a four-factor model of general safety performance. The first factor is labeled Using Personal Protective Equipment, which involves using respiratory equipment and protective clothing when engineering and work 
controls are not feasible to control exposure to hazards. A second category, Engaging in Work Practices to Reduce Risk, involves performing tasks to assure safety, which includes methods to minimize hazards, such as barriers or isolation. The third category, Communicating Health and Safety Information, measures the communication of hazards, accidents, incidents, etc. to appropriate personnel, while the fourth category, Exercising Employee Rights and Responsibilities, involves exercising these rights and responsibilities to laws and regulations.

It is important to understand what predicts variations in safety performance. Griffin and Neal (2000) suggest that the determinants of safety performance are knowledge, skill, and motivation. The authors studied a population of manufacturing and mining employees in Australia to aid in development of a framework of employee perceptions of safety in the workplace. In their model, they distinguish between proximal and distal causes of safety performance. Proximal causes of safety performance include the knowledge and skills employees need to perform certain safety behaviors as well as the motivation of these employees to perform the behaviors. Distal antecedents of safety are factors that influence safety performance via effects on employee knowledge, skill and motivation to comply with and participate in safety activities, like personality constructs (Wallace \& Vodanovich, 2003a) or job security (Probst \& Brubaker, 2001). As just shown, researchers have 
identified numerous antecedents of safety performance, yet little research to date considers work-family conflict as a predictor of safety performance.

Safety has been studied in various industrial sectors, such as manufacturing and mining organizations (Griffin \& Neal, 2000), woodprocessing companies (Varonen \& Mattila, 2000), chemical processing plants (Hofmann \& Stetzer, 1996), metal processing plants (Zohar, 2000) and areas such as wholesale and retail trade, finance and service (Smith, Huang, Ho, \& Chen, 2006). Construction-related safety is the focus of the present study. Several researchers have examined safety issues in construction industries. In a study of Hong Kong construction workers, it was found that safety attitudes predicted occupational injuries (Siu, Phillips, \& Leung, 2004). Further, the researchers asserted, "It seems that it is possible to assess construction workers' safety attitudes to predict injuries, so that proactive action can be taken" (Siu, et al., 2004, p. 364). Gillen, Baltz, Gassel, Kirsch, and Vaccaro (2002) approached the relationship between safety and injuries in construction workers from a different angle. They evaluated construction workers who were currently injured and surveyed their perceptions regarding workplace safety climate, among other variables. Safety climate was found to have a unique contribution in explaining the variance in injury severity. In a study by Chen, Rosencrance, and Hammer (2005), it was found that work-to-family conflict significantly predicted construction worker's mental and physical health, as well as frequent injuries and chronic pain on the job. These results suggest that construction workers are 
an appropriate population in which to study safety performance and work-family issues.

The present study utilizes the model proposed by Griffin and Neal (2000) to understand the determinants of safety performance and the theory of limited cognitive resources to argue that family-to-work conflict negatively affects safety performance through its effect on workplace cognitive failure. The next section provide rationale for how safety climate moderates the relationship between workplace cognitive failure and safety performance. Lastly, I summarize the argument that family-to-work conflict should be viewed as a stressor that impedes limited cognitive resources, causing cognitive errors on the job which led to a decrease in levels of safety performance.

\section{Safety Climate as a Moderator}

In the present study, I hypothesize that an organization's safety climate changes the relationship between workplace cognitive failure and safety performance for its employees. According to Neal and Griffin (2004), safety climate refers to perceptions of the organization's policies, procedures and practices relating to safety. Safety climate is a shared perception of safety's value in the work environment. Safety climate can be thought of as a higherorder factor comprised of several specific first-order factors. In this conceptualization, the higher order factor should reflect the extent to which the employees feel safety is valued in the organization, while the first order factors of safety climate reflect the perceptions of policies, procedures and rewards 
related to safety (Griffin \& Neal, 2000). As for measuring these safety climate factors, there is currently no clear agreement. Huang, Ho, Smith, and Chen (2006, p. 425), assert that "there is no consensus about what dimensions constitute the safety climate." Zohar (1980) identified eight dimensions of safety climate. These dimensions included management attitudes toward safety, effects of safe conduct on promotion, status of the safety officer, the status of the safety committee, importance of safety training, level of risk at work place, the effect of safety conduct on social status, and the effects of the required work pace on safety. Both Brown and Holmes (1986) and Dedobbeleer and BeLand (1991) have revised Zohar's (1980) original scale. Additionally, management values have been measured in numerous ways, the most common being management commitment to safety (Huang, et al., 2006). Management commitment to safety does not seem to have a clear definition, for example, Zohar (1980, p. 101) concluded that management commitment to safety has a "multitude of expressions" and "such expressions might be the establishment of job-training programs, relegation of executive authority to safety officials, participation of high-level managers in safety committees, and taking safety into consideration in job design." Management commitment to safety has been studied in ways that include whether workers perceive that safety is important to management (Diaz \& Cabrera, 1997), management attitudes toward safety (Dedobbeleer \& BeLand, 1991), and management concern for employee well-being (Brown \& Holmes, 1986): More recent work by Zohar makes a distinction between organizational- 
level and specific group-level safety climate (Zohar \& Luria, 2005). These scales focus on three content areas: active practices (e.g. monitoring, enforcing), proactive practices (e.g. promoting learning, development) and declarative practices (e.g. declaring, informing).

It has been suggested that safety climate is an antecedent of safety performance (Griffin \& Neal, 2000; Huang, et al., 2006). Similarly, Hofmann and Stetzer (1996) have asserted that safety climate influences the work context, so in turn is likely to influence safety performance. Studying a population of employees at a chemical processing plant, safety outcomes measured included unsafe behaviors and accidents. A list of unsafe behaviors was derived from a review of organizational materials. Actual accidents were measured as the number of recordable accidents. Results found that safety climate, controlling for role overload, was significantly related to unsafe behaviors. It was also found that safety climate was negatively related to actual accidents, meaning that a better safety climate was associated with less actual accidents. Cooper and Phillips (2004) additionally found an empirical link between a limited set of safety climate perceptions and actual safety behavior, but suggested that the overall relationship between these two variables is complex. Utilizing a population of employees at a packaging production plant, the authors measured safety climate and observed percent safe, which was an observational measure of actual employee behavior at the workplace. It was found that although there was an empirical link between safety climate scores and actual safety behavior, 
the magnitude of change in perceptual safety climate scores does not necessarily match actual changes in safety behavior. For example, the perceptions of the importance of safety training were predictive of actual levels of safety behavior, while perceived management action was not. Clarke (2006) conducted a metaanalysis to examine the criterion-related validity of the relationships between safety climate, safety performance, and accidents and injuries in the workplace. Results showed that both categories of safety performance, compliance and participation, were related to organizational safety climate. Safety participation was found to have the stronger link. The author suggests this is because in a positive safety climate, when management demonstrates commitment toward safety, employees are willing to reciprocate by broadening their roles to include more safety-related Organizational Citizenship Behaviors, which increase safety participation. Further results clarified the directionality of the relationship, in that organizational safety climate influences accident and injury rates through its effect on safety performance. Based on this research, the present study tests safety climate as a potential moderator between cognitive failure and safety performance.

As previously discussed, cognitive failure has been associated with safety behavior. Safety climate serves as one of many antecedents that could influence safety behavior (Neal \& Griffin, 2004), so there is a known connection between the two constructs. It is predicted that the relationship between workplace cognitive failure and safety performance changes as a function of the 
level of safety climate. A strong safety climate will decrease the relationship between workplace cognitive failure and safety performance.

Zohar's (2003b) discussion of the antecedents of safety climate may help in understanding how safety climate is a potential moderator in the relationship between cognitive failure and safety performance. Antecedents of safety climate itself include production technology, personal beliefs and leadership quality (Zohar, 2003b). The first antecedent discussed involves differences in production technology. Different risk levels are created because production technology can differ across organizational units. Most organizations have units that are riskier than others. Despite stress from work-family conflict, fewer cognitive errors may occur if the workplace has a low risk level. Personal beliefs about safety, as well as attributions of supervisors, are a second antecedent to safety climate. For example, accidents may be attributed to external or internal factors, and responsibility for safety may be thought to lie in the hands of either management or the subordinates. Fewer cognitive errors might occur depending on the personal safety beliefs held by the employee as well as the supervisor. Leadership quality, the third antecedent mentioned, involves quality of interactions between the supervisors and subordinates. For instance, higher quality interactions result in a greater safety-emphasis, which in turn influences the group's safety perceptions (Zohar, 2003b). If interactions have a high safetyemphasis, the effect of cognitive failure on safety performance could decrease. 
This study focuses on the outcomes of the stress from conflicting work and family roles. Safety climate is a critical issue to address since the relationship between the mediator proposed in this study (workplace cognitive failure) and the outcome of interest (safety performance) may change as a function of safety climate. Next, I discuss the present study's hypotheses.

\section{Present Study and Hypotheses}

The purpose of the present study was to test a model of safety performance in the workplace. This study extends current understanding of workplace safety behaviors. First of all, this study contributes to both the work-family and safety fields of research. It is hypothesized that family-to-work conflict places additional demands on employees' limited valuable cognitive resources, causing cognitive errors on the job, and thereby reducing levels of safety compliance and participation. It is further posited that the relationship between workplace cognitive failure and safety performance will change as a function of how much employees' feel safety is valued in the organization (safety climate). Specifically, this study tests the hypothesis that high family-to-work conflict will result in increased levels of workplace cognitive failure, which in turn causes lower levels of safety performance (compliance and participation). Workplace cognitive failure is expected to mediate the relationship between family-to-work conflict and safety performance. However, it is also expected that level of safety climate will ameliorate the negative relationship between workplace cognitive failure and safety performance. 
Hypotheses

Hypothesis 1a: Family-to-work conflict will be negatively related to safety participation.

Hypothesis 1 : Family-to-work conflict will be negatively related to safety compliance.

Hypothesis 2: Family-to-work conflict will be positively related to workplace cognitive failure.

Hypothesis $3 a$ : Workplace cognitive failure will be negatively related to safety participation.

Hypothesis $3 b$ : Workplace cognitive failure will be negatively related to safety compliance.

Hypothesis 4a: Workplace cognitive failure will mediate the relationship between family-to-work conflict and safety participation.

Hypothesis 4b: Workplace cognitive failure will mediate the relationship between family-to-work conflict and safety compliance.

Hypothesis $5 a$ : Safety climate will moderate the relationship between workplace cognitive failure and safety participation, such that when safety climate is high the negative relationship between cognitive failure and safety participation will be weaker.

Hypothesis $5 b$ : Safety climate will moderate the relationship between workplace cognitive failure and safety compliance, such that when safety 
climate is high the negative relationship between cognitive failure and safety compliance will be weaker. 


\section{METHOD}

\section{Participants and Procedure}

The data were treated as archival. The participants in this study were employees of a city-owned water utility plant, consisting of office workers, engineers, and management, but with the majority of employees being in construction. I conducted three focus groups prior to administration of the survey to aid in survey development. Focus groups were separated by job category, including a group of nine non-supervisory employees, a group of three crew leaders, and a group of six supervisors. The same general process and method of questioning was used in each group (see Appendix A for the focus group process). Participants first signed an informed consent form (see Appendix B), followed by a demographics questionnaire (see Appendix C). Questions asked in the crew leader and supervisor focus groups were identical but question phrasing differed slightly for the non-supervisory focus group (see Appendix D for a list of questions). Results from the focus group discussions were used to ascertain the survey included issues the organization's employees deemed important.

Employees were invited to participate in a survey during a class session at the company's 2006 Interstate Safety and Health Fair (see Appendix E for a flyer). I administered the survey on September 28, 2006. Three classes were held, each class consisting of approximately 50 participants. The total sample size was 134 out of 150 for an $89 \%$ response rate. Results from a power analysis 
suggested that for a sample size of 134 with an assumed population correlations coefficient of .25 , our estimate of power is approximately between .80 and .83 $(\beta>2.88, \alpha$ for a two sided test $=.05)$.

Participants were $85 \%$ male, $74 \%$ white, with $47 \%$ having completed some college or an associate's degree. Forty-eight percent of the employees were married, and $42 \%$ cared for children. The session was required for participants of the Safety and Health Fair. Members of the research team supervised the process, and respondents were promised confidentiality. Participants first filled out informed consent forms (see Appendix F). Surveys took approximately 30 minutes to complete. They were filled out on company time and were completely voluntary (see Appendix G for a version of the survey with scales delineated). Participants were informed that they were not required in any way by the company to fill out the survey and that they could withdraw their participation at any time.

\section{Measures}

Family-to-work conflict. Work-family conflict is a form of interrole conflict in which the role pressures from work and family domains are mutually incompatible in some respect. There are two dimensions of work-family conflict, but only one will be utilized in the present study. Family-to-work conflict was measured using a modified version of a scale developed by Netemeyer, Boles, and McMurrian (1996). Family-to-work conflict occurs when family interferes with work $(\alpha=.89)$. The measure was reduced from five to 
four total items, in order to shorten the survey length. The measure asks participants to indicate the extent to which they agree or disagree with each of the items using a five-point scale ranging from 1 (strongly disagree) to 5 (strongly agree). A sample item for the family-to-work conflict subscale is: $I$ have to put off doing things at work because of demands on my time at home.

Safety climate. This construct refers to perceptions of the policies, procedures and practices relating to safety, and can be seen as a shared perception of safety's value in the work environment. Safety climate was assessed using a measure based on Zohar's (1980) original scale, later revised by Dedobbeleer and BeLand (1991).There are two subscales in this measure of safety climate: three items measure management's commitment to safety ( $\alpha=$ $.90)$, and five items measure worker involvement in safety activities $(\alpha=.61)$. The measure asks participants to indicate the extent to which they agree or disagree with each of the items using a five-point scale ranging from 1 (strongly disagree) to 5 (strongly agree). A sample item for the management's commitment to safety subscale is: Worker safety practices are important to management. A sample item for the worker involvement in safety activities subscale is: I have control over safety on the job.

Safety participation and compliance. Safety performance on the job is determined by levels of safety participation and safety compliance. Safety Participation is the extent to which individuals participated in safety-related activities. Safety compliance involves adhering to safety procedures and 
carrying out work in a safe manner. Safety performance was measured using a scale developed by Neal, Griffin, and Hart (2000). This measure contains 8 items: 4 items measuring safety participation $(\alpha=.79)$ and 4 items measuring safety compliance $(\alpha=.90)$. Responses range from strongly disagree (1) to strongly agree (5). A sample item for the safety participation subscale is: $I$ promote the safety program within the organization. A sample item for the safety compliance subscale is: I use all the necessary safety equipment to do my job.

Workplace cognitive failure. Workplace cognitive failure refers to cognitively based errors that occur during the performance of a task that the person is normally successful in executing, and specifically includes the regulatory skills that account for work behavior. The Workplace Cognitive Failure Scale (WCFS), developed by Wallace and Chen (2005), was used. Fifteen items measured three components of workplace cognitive failure. Five items measure the subscale of memory, which refers to information retrieval failures $(\alpha=.79)$. Five items measure the subscale of attention, which refers to failures in perception $(\alpha=.84)$. Five items measure the subscale of action, which refers to performance of unintended actions $(\alpha=.75)$. Responses ranging from 1 (strongly disagree) to 5 (strongly agree). A sample item for the memory subscale is: Cannot remember what materials are required to complete a particular task? A sample item for the attention subscale is: Day-dream when you ought to be 
listening to somebody? A sample item for the action subscale is: Accidentally started or stopped the wrong machine?

Control variables. Since previous research has suggested links among age, gender, and workplace accidents (e.g., Liao, Arvey, Butler, \& Nutting, 2001; Loughlin \& Frone, 2004), respondents' age and sex were considered as control variables in this study. Other control variables considered include ethnicity, number of hours worked, number of children, and whether or not the employee cares for elderly parents.

Analyses

First, I conducted a descriptive analysis of the data. I screened for outliers by examining item-level statistics such as range, minimum and maximum values. Further, I conducted a scale and item reliability analyses. No abnormalities were found.

The first question of interest concerns whether workplace cognitive failure is a mediator between family-to-work conflict and safety performance (i.e., safety participation and safety compliance). According to Baron and Kenny (1986), the first step in mediation must show that the initial variable is correlated with the outcome. Assessing hypotheses 1 and 2, two regression analyses were conducted to determine if family-to-work conflict predicts safety participation and safety compliance. The second step in mediation must show that the initial variable is correlated with the mediator. Assessing hypothesis 3, a regression analysis was conducted to determine if family-to-work conflict predicts 
workplace cognitive failure. In the third step, the mediator must be shown to affect the outcome variable. Assessing hypotheses 4 and 5, two regression analyses were conducted to determine if workplace cognitive failure predicts safety participation and safety compliance. In the last step to support full mediation, the effect of the initial variable on the outcome controlling for the mediator should be zero. Assessing hypotheses 6 and 7, two regression analyses were conducted to determine if family-to-work conflict no longer significantly predicts safety participation and safety compliance when controlling for workplace cognitive failure.

The second question of interest concerns whether safety climate serves as a moderator in the relationship between workplace cognitive failure and safety performance (i.e., safety compliance and safety participation). To test for moderation, hierarchical multiple regression analyses were calculated. After centering the IV (workplace cognitive failure) and the moderator (safety climate), an interaction term was created for the IV. The control variables were entered first. In the second step, workplace cognitive failure and safety climate were entered. The interaction term for workplace cognitive failure was entered in step three. Assessing hypothesis 5, I determined whether the interaction of centered workplace cognitive failure and centered safety climate was statistically significant, which would mean that the relationship between centered workplace cognitive failure and safety performance (safety participation and safety compliance) depends on centered safety climate. 


\section{RESULTS}

\section{Missing Data}

There was some missing data on the constructs used in this study. Scale scores for each respondent were computed by finding the mean of the items making up the various scales. The means were calculated according to a $66 \%$ response rule. A scale score was created only for those participants who answered at least $66 \%$ of the items. If at least $66 \%$ of the items that make up the scale were not answered then the respondent did not receive a scale score and was counted as missing for any subsequent analyses using that construct.

\section{Demographics}

Tables 1 and 2 contain descriptive data for the sample demographics. The sample contained 134 participants. Eighty-five percent of the participants were male, with the average age being 39 years old. Seventy-four percent of participants were Caucasian. The largest grouping of participants had completed some college or had an associate's degree (47\%), and felt they had enough money with a little left over sometimes (49\%). Thirty-two percent earned between $\$ 55,000$ and $\$ 70,000$ per year $(32 \%)$. The majority of participants held non-supervisory roles $(76 \%)$. Forty-eight percent of participants indicated that they were currently married (48\%), with $42 \%$ caring for children and $18 \%$ caring for elderly parents. Regarding work experience, an average of about 19 years of full-time work experience and about 4 years of part-time work 
experience was reported. Participants reported an average of about 8 years working for the Water Bureau, and about 6 years on their current work site. Control Variables

Since previous research has suggested links among gender and workplace accidents (Loughlin \& Frone, 2004), respondents' gender served as a control variable in this study. The control variable was correlated with the outcomes of interest. Workplace Cognitive Failure and Safety Participation were not significantly correlated with the control variable, though Safety Compliance was significantly correlated with gender $(R=.21, p<.05)$ (see Table 3 ).

\section{Hypothesis Testing}

Tables 4 and 5 contain data for hypotheses 1 through 4 . Hypothesis 1 stated that family-to-work conflict will relate to safety participation (1a) and safety compliance (1b). The first step in testing mediation is to regress the dependent variable on the independent variable. For Hypothesis 1a, the dependent variable was safety participation. Family-to-work conflict, together with the control variable of gender, did not account for a significant proportion of the variance in safety participation $\left(\mathrm{R}^{2}=.00, \mathrm{~F}(2,124)=.25, p=\mathrm{ns}\right)$. For Hypothesis $1 \mathrm{~b}$, the dependent variable was safety compliance. Family-to-work conflict, together with the control variable of gender, did not account for a significant proportion of the variance in safety compliance $\left(\mathrm{R}^{2}=.05, \mathrm{~F}(2,124)\right.$ $=3.27, p=\mathrm{ns})$. Hypotheses $1 \mathrm{a}$ and $1 \mathrm{~b}$ were not supported. 
The second step in testing mediation is to show that the independent variable is significantly related to the mediator. Hypothesis 2 stated that familyto-work conflict is positively related to workplace cognitive failure. Family-towork conflict, together with the control variable of gender, accounted for a significant proportion of the variance in workplace cognitive failure $\left(R^{2}=.18, F\right.$ $(2,127)=13.52, p<.01)$. Family-to-work conflict accounted for unique variance in workplace cognitive failure $(\beta=.42, \mathrm{p}<.01)$. Holding gender constant, for every one standard deviation increase in family-to-work conflict, there is a corresponding .42 standard deviation increase in workplace cognitive failure.

Hypothesis 3 stated that workplace cognitive failure relates to safety participation (3a) and safety compliance (3b). Workplace cognitive failure, together with the control variable of gender, accounted for a significant proportion of the variance in safety participation $\left(R^{2}=.09, F(2,125)=6.26, p<\right.$ .01). Workplace cognitive failure accounted for unique variance in safety participation $(\beta=-.30, \mathrm{p}<.01)$. Holding gender constant, for every one standard deviation increase in workplace cognitive failure, there is a corresponding .30 standard deviation decrease in safety participation. Workplace cognitive failure, together with the control variable of gender, accounted for a significant proportion of the variance in safety compliance $\left(R^{2}=.23, F(2,125)=17.92, p\right.$ $<.01)$. Workplace cognitive failure accounted for unique variance in safety compliance $(\beta=-.45, \mathrm{p}<.01)$. Holding gender constant, for every one standard 
deviation increase in workplace cognitive failure, there is a corresponding . 45 standard deviation decrease in safety compliance.

Hypothesis 4 stated that workplace cognitive failure will mediate the relationship between family-to-work conflict and safety participation (4a) and family-to-work conflict and safety compliance (4b). Since hypotheses $1 \mathrm{a}$ and $1 \mathrm{~b}$ were not significant, it is not possible to support mediation. When workplace cognitive failure was added to the model, there is additional variance in safety participation accounted for, $\Delta \mathrm{R}^{2}=.09, \mathrm{~F}(1,121)=11.46, \mathrm{p}<.05$. Only workplace cognitive failure explained unique variance in safety participation $(\beta$ $=-.32, \mathrm{p}<.01)$. Holding gender and family-to-work conflict constant, for every one standard deviation increase in workplace cognitive failure, there is a corresponding .32 standard deviation decrease in safety participation. When workplace cognitive failure is added to the model, there is additional variance in safety compliance accounted for, $\Delta R^{2}=.18, F(1,121)=28.88, p<.05$. Workplace cognitive failure explains unique variance in safety compliance $(\beta=$ $-.47, \mathrm{p}<.01)$. Gender explains unique variance in safety compliance $(\beta=-.20$, $\mathrm{p}<.01)$. Holding gender and family-to-work conflict constant, for every one standard deviation increase in workplace cognitive failure, there is a corresponding .47 standard deviation decrease in safety participation.

Tables 6 and 7 contain data for hypothesis 5 . Hypothesis 5 stated that the negative effects of workplace cognitive failure on safety participation (5a) and safety compliance (5b) would vary based on the level of safety climate. In 
testing moderation, the first step is to test for main effects of the independent variable and the moderator. The second step is to use hierarchical regression to see if the interaction between the independent variable and the moderator account for any additional variance in the dependent variable, beyond that which is accounted for by the main effects. Workplace cognitive failure and safety climate, together with the control variable of gender, did account for a significant proportion of the variance in safety participation, $R^{2}=.10, F(3,125)$ $=4.27, p<.01$. Further examination of the main effects revealed that workplace cognitive failure significantly accounted for some unique variance in safety participation $(\beta=-.30, p<.01)$, consistent with Hypothesis $3 \mathrm{a}$. The Workplace Cognitive Failure X Safety Climate interaction entered at Step 3 did not account for a significant increment in safety participation, $\Delta R^{2}=.01, F(1,121)=1.77, p$ $<.01, B=.19, p=$ ns. Hypothesis 5 a was not supported.

Workplace cognitive failure and safety climate, together with the control variable of gender, did account for a significant proportion of the variance in safety compliance, $R^{2}=.35, F(3,125)=21.52, \mathrm{p}<.01$. Further examination of the main effects revealed that workplace cognitive failure significantly accounted for some unique variance in safety compliance $(B=-.36, p<.01)$, consistent with Hypothesis $3 b$. Safety climate significantly accounted for some unique variance in safety compliance $(B=.36, p<.01)$. The Workplace Cognitive Failure X Safety Climate interaction entered at Step 2 did not account 
for a significant increment in safety compliance, $\Delta R^{2}=.07, F(1,121)=1.26$. Hypothesis $5 \mathrm{~b}$ was not supported.

\section{Follow-up Post Hoc Analyses}

In prior research, some authors have focused on an overall measure of workfamily conflict (e.g., Cooke \& Rousseau, 1984; Kopelman, Greenhaus, \& Connolly, 1983), which has been related to a number of outcomes. This suggests that the dimensional effects may not be able to be distinguished. Therefore I tested for an overall work-family conflict measure predicting both safety participation and safety compliance (see Table 8). Work-family conflict, together with the control variable of gender, did not account for a significant proportion of the variance in safety participation, $\mathrm{R}^{2}=.00, \mathrm{~F}(2,124)=.14, p=$ ns. Work-family conflict, together with the control variable of gender, did account for a significant proportion of the variance in safety compliance, $\mathrm{R}^{2}=$ $.06, \mathrm{~F}(2,124)=3.52, p<.05$, although only gender accounted for unique variance in safety compliance $(\beta=.37, \mathrm{p}<.05)$. Since the first step to support mediation was not significant, I did not conduct the subsequent analytical steps.

I tested the relationship between each direction of work-family conflict and both safety participation and safety compliance, while controlling for the other direction of work-family conflict (see Table 8). Family-to-work conflict, together with work-to-family conflict and the control variable of gender, did not account for a significant proportion of the variance in safety participation, $\mathrm{R}^{2}=$ $.02, \mathrm{~F}(3,124)=.63, p=\mathrm{ns}$. Family-to-work conflict, together with work-to- 
family conflict and the control variable of gender, did not account for a significant proportion of the variance in safety compliance, $\mathrm{R}^{2}=.06, \mathrm{~F}(3,124)$ $=2.41, p=$ ns. Similarly, since the first step to support mediation was not significant, I did not conduct the subsequent analytical steps.

Characteristics of the family domain can have an effect on work-family conflict. For example, Behson (2002) found that work-family conflict is higher among those who have children at home. A logical conclusion is that the construct of work-family conflict is more relevant to those participants caring for or living with family members. I tested the relationship between family-towork conflict and safety performance using only data from participants who had a spouse or partner, or cared for children or aging parents (see Table 8). Familyto-work conflict, together with the control variable of gender, did not account for a significant proportion of the variance in safety participation, $\mathrm{R}^{2}=.02, \mathrm{~F}(2$, $90)=.63, p=$ ns. Family-to-work conflict, together with the control variable of gender, did not account for a significant proportion of the variance in safety compliance, $\mathrm{R}^{2}=.06, \mathrm{~F}(2,90)=2.66, p=\mathrm{ns}$. Similarly, since the first step to support mediation was not significant, I did not conduct the subsequent analytical steps.

I tested the proposed mediation with a different safety outcome. Instead of safety performance (safety participation and safety compliance), the valence component of safety motivation was used (see Table 9). Cullen and Hammer (2007) found safety motivation and safety performance to be significantly 
correlated. Since they are highly related constructs, it seems logical to test the proposed mediation with safety motivation as the outcome. The valence component of safety motivation refers to how motivating the rewards resulting from safety behavior are. Family-to-work conflict, together with the control variable of gender, did account for a significant proportion of the variance in safety motivation valence, $\mathrm{R}^{2}=.07, \mathrm{~F}(2,127)=4.34, p<.05$. Family-to-work accounted for unique variance in safety motivation valence $(\beta=-.12, \mathrm{p}<.05)$. For every one-unit increase in family-to-work conflict, there was a corresponding .12 decrease in safety motivation valence. Family-to-work conflict, together with the control variable of gender, accounted for a significant proportion of the variance in workplace cognitive failure, $R^{2}=.42, F(2,127)=$ $13.52, p<.01$. Family-to-work conflict accounted for unique variance in workplace cognitive failure $(\beta=.31, \mathrm{p}<.01)$. Holding gender constant, for every one-unit increase in family-to-work conflict, there was a corresponding .31 increase in workplace cognitive failure. Workplace cognitive failure, together with the control variable of gender, did account for a significant proportion of the variance in safety motivation valence, $\mathrm{R}^{2}=.31, \mathrm{~F}(2,128)=$ $27.98, p<.01$. Workplace cognitive failure accounted for unique variance in safety motivation valence $(\beta=-.45, \mathrm{p}<.05)$. Holding gender constant, for every one-unit increase in workplace cognitive failure, there was a corresponding .45 decrease in safety motivation valence. 


\section{DISCUSSION}

This study examines the effects of work-family conflict on safety performance among a sample consisting primarily of construction workers; and to assess safety climate's role as a moderator in this relationship. This was accomplished by examining variations in safety performance via the effects of family-to-work conflict on workplace cognitive failure. It is widely recognized that work-family conflict leads to many undesirable outcomes at home, at work, and for the individual. The present study adds support to the argument that employers need to pay attention to the work-family needs of their workers.

The results suggest mixed support for the hypotheses. First, I hypothesized that family-to-work conflict would be significantly related to levels of both safety participation and safety compliance. These relationships were not found to be significant. There are several plausible explanations for this finding. First of all, the present sample consists of $85 \%$ males. It is possible that findings based on the Cullen and Hammer sample, which consisted of primarily female healthcare workers, may not generalize to a male-dominated sample of construction workers. Some research has found women to have higher levels of work-family conflict than their male counterparts (Behson, 2002;

Gutek, Searle, \& Klepa, 1991). Loscocco (1997) found that men reported more work-to-family intrusions, while women reported more family-to-work intrusions. This is important to consider since the present study was particularly interested in family-to-work conflict. 
Next, it was hypothesized that the level of family-to-work conflict would be significantly related to workplace cognitive failure. This relationship was found to be significant. Further, I hypothesized that workplace cognitive failure would be significantly related to both safety participation and safety compliance. Both of these relationships were also significant. Family-to-work conflict is significantly related to workplace cognitive failure, which in turn is significantly related to levels of both safety participation and safety compliance. These results suggest that family-to-work conflict is an important predictor to consider when studying workplace cognitive failure. Similarly, workplace cognitive failure is significantly related to levels of safety performance. Since family-to-work conflict does not have a significant relationship with safety performance, there may be an unaccounted variable impacting workplace cognitive failure. Martin (1983) found conscientiousness to be related to cognitive failure, as well as workplace safety behavior and accidents. Conscientiousness may be a factor to consider in future research.

The hypotheses regarding workplace cognitive failure as a mediator between family-to-work conflict and both safety participation and safety compliance were not shown to be significant. According to Baron and Kenny (1986), the first step must be significant in order to The last two hypotheses, regarding safety climate as a moderator in the relationship between workplace cognitive failure and both safety participation and safety compliance, similarly were not significant. Since a majority of the sample performs work duties off- 
location, a possible explanation for this finding is that the sense of safety climate may not be as salient as in traditional jobs. It may be that the individual crew leader of each project has a stronger influence than the level of organizational safety climate. For clarification, two independent parameters describe safety climate (Zohar, 2003a). The strength of climate refers to the internal consistency with which climate perceptions are held. A weak safety climate would thus allude to a lack of agreement on perceptions of the organization's value of safety. The level of climate refers to the relative position of the climate mean on a continuum; thus a low climate refers to shared perceptions that safety is not highly valued in the organization. Although results show that the organization had a moderately high safety climate, there may have been a lack of agreement between work groups.

Post-hoc analyses. Further analyses revealed that the overall measure of work-family conflict similarly did not significantly predict safety performance. Similarly, controlling for work-to-family conflict, family-to-work conflict did not significantly predict safety performance. Including only participants with a spouse or partner, or cared for children or aging parents did not change the relationship between family-to-work conflict and safety performance to be significant. Reasons for a lack of significance in these post-hoc analyses can be attributed to reasoning provided previously. Based on the context and participants, there is not a strong relationship between work-family conflict and safety performance. 
Implications. This study has implications for researchers, employees, and organizations. First, the study significantly contributes to both the work-family and safety literatures. Only one study has been conducted linking work-family conflict and safety, with the exception being Cullen and Hammer (2007). The present study extends Cullen and Hammer's study to a different population and makes a unique contribution by attempting to better understand the psychological mechanisms underlying the relationship between work-family conflict and safety. Although the proposed mediation was not found to be significant, follow-up analyses suggest the valence component of safety motivation is a more appropriate outcome for the proposed mediation than safety performance. This finding extends the current state of the literature. Considering the importance of both work-family conflict and safety in the field of Occupational Health Psychology, the merging of the constructs will be beneficial for the further development of this relatively new field of psychology.

Second, as can be inferred from the statistics presented at the beginning of this thesis, both work-family conflict and safety not only play an important role in the workplace, but also in society. Work and family are two of the most important domains in adult lives, and the more that is known about the conflict between these two roles, the more progress can be made towards minimizing the negative effects of this conflict for individuals. Similarly, safety plays an important role for employees. If injuries and illnesses can be prevented, employees are better off. Their health is important to quality of personal life, as 
well as quality of family life. Work-family conflict is viewed in this study as a safety hazard, and a goal is to help substantiate the roles of work and family interface in safety. When workers are preoccupied with thoughts or concerns about work-family conflict, they are more likely to be injured due to distraction.

Third, this research could have a direct impact on the workplace. It could lead either managers or safety directors to pay more attention to conflict between employees' work and family lives. If the cost of injuries and illnesses can be minimized, businesses can reduce costs. Although family-to-work conflict was not shown to have a direct impact on safety performance, it is a significant predictor of workplace cognitive failure. Workplace cognitive failure, in turn, does relate significantly to safety performance. For example, if management is aware of the connection between these three constructs, family friendly policies or procedures are more likely to be employed or, if they are already in place, usage may be more strongly encouraged. Training for supervisors could include sensitivity training towards work-family issues. Management is more likely to understand the importance and employ tactics to avoid negative safety outcomes in the future.

Additionally, Thomas and Ganster (1995) named four reasons why we should strive to understand the causes of stress and strain in the workplace (including work-family conflict). The first of these is the amount that stressrelated illnesses cost the American economy, which may be as high as $\$ 150$ billion. A second reason derives from the companies that have been losing stress 
litigation cases in the courtroom. Companies need to prove to courtrooms that they are trying to minimize stress and strain in the workplace. Third, occupational stress has been shown to lead to negative health outcomes, and last of all, employees under stress can cost the organization money from reduced productivity, lost time, and higher accident levels, which is of importance in the present study.

In order to alleviate work-family conflict, it is important to understand how organizations can support their employees. As discussed previously, decreased work-family conflict can lead to beneficial outcomes for employers, employees, and employees' families. Further, this study has demonstrated a connection between family-to-work conflict and workplace cognitive failure. Research has been conducted regarding effects of family friendly workplace supports on employees. Neal, Chapman, Ingersoll-Dayton, and Emlen (1993) make a distinction between three types of workplace supports provided by organizations: policies, services, and benefits. An example of policies includes flexible work arrangements, while an example of services includes resources or referral information supplied for employees about issues such as dependent care, and thirdly, an example of benefits would be paid family leave. Important for the present study, which involves a sample consisting of mostly construction workers, research has shown that managerial and professional workers are more likely to have access to and take advantage of work-family policies (Glass \& Estes, 1997). The workers in the present study may lack work-family supports. 
While these formal policies are implemented with the expectation that they decrease work-family conflict for employees, the desired impact of reducing work-family conflict has not always been found (Kossek \& Ozeki, 1998). This leads to the idea that workplace supports should be further differentiated into formal and informal supports when considering work-family conflict (Hammer, Kossek, Alexander, \& Daniels, 2006). Formal family supportive organizational policies and practices include dependent care supports, healthcare, alternative work arrangements, and adequate compensation, while informal family supportive organizational culture and climate are defined as: "the shared assumptions, beliefs, and values regarding the extent to which an organization supports and values the integration of employees' work and family lives" (Thompson, Beauvis, \& Lyness, 1999, p.394). This distinction is important because previous research has demonstrated that informal supervisory support for work and family may be more important than formal workplace policies and supports offered by companies (Kossek \& Nichol, 1992). Allen (2001) found that employees that perceive their organization as being less family-supportive report more work-family conflict, as well as less job satisfaction, less organizational commitment and greater turnover intentions, than employees that perceive their organization as being more family-supportive. Further, although some previous studies have found the implementation of workplace supports to be associated with positive outcomes, research has also demonstrated that an unsupportive organizational culture may 
undermine the effectiveness of such programs (Thompson, Thomas, \& Maier, 1992). This research suggests the moderating effects of work and family culture (in which supervisor support is a critical component) on the relationship between use of supports and beneficial employee outcomes. More specifically, when the work and family culture is not supportive, provision of formal supports does not have as significant of an impact on employee's work and family conflict and other health and work outcomes as when the culture is supportive (Allen, 2001; O'Driscoll et al., 2003; Thompson et al., 1999). O'Driscoll et al. examined the effects of work-family benefits, family-oriented organizational support and supervisor support for work-family balance as relevant for alleviating work-family conflict. It was found that availability and usage of formal organizational supports was not sufficient to generate stress reduction or lower work-family conflict. The authors suggest that a necessary condition for the alleviation of work-family conflict may be the development of a workfamily supportive organizational culture.

\section{Limitations}

Although the results of the study extend previous literature, it is appropriate to recognize potential limitations. First, a cross-sectional design was employed. This design does not allow researchers to make conclusive inferences concerning the precedence of the relationships depicted in the model. Second, the use of all self-report data suggests the possibility of common method bias, meaning that the variance in the measurement of constructs could possibly be 
attributed to the instrumentation used rather than to the constructs of interest. Wallace and Vodanovich (2003b) did find a significant relationship between self and supervisory reports of on-the-job accidents, which supports the use of selfreport data in safety research. A third possible limitation is that the nature of this sample could potentially limit the applicability of the findings to other settings. Although the purpose of this study was to study construction workers, the sample does limit the generalizeability of the results. Because of the nature of this occupation, the sample consisted mainly of male employees ( $85 \%)$. Thus, future studies should seek replication in a different industry with a less homogenous sample.

\section{Suggestions for Future Research}

Researchers interested in safety behavior should explore other predictors of safety performance. In the present study, workplace cognitive failure was found to be an important predictor of safety performance. Researchers should explore predictors that may have interactive or additive effects on safety performance, along with the effect of workplace cognitive failure. Further, safety motivation may play an important role in prediction of safety performance. Cullen and Hammer (2007) found significant correlations between the two dimensions of safety performance, safety compliance and safety participation, and their corresponding safety motivation dimensions. Future research should take safety motivation into account. 
Researchers should further examine safety climate's potential moderating role. Although safety climate was not found to moderate the relationship between workplace cognitive failure and safety performance in this study, future research should test this relationship in a different sample. This moderation may prove significant in different workplace structures. As further support, other research has found safety climate to be a moderator. For example, Probst and Brubaker (2001) found safety climate to moderate the relationship job insecurity and safety performance.

It may be beneficial for future research to explore the family characteristics that impact findings. The present study did not differentiate between family compositions. Future researchers should compare results for different family situations, such as single-parent families, large families, families that contain members with disabilities or dual-earner couples. For example, Hammer et al. (1997) found that number of children in the family was positively associated with work-family conflict such that the more children a couple had the more conflict they reported between work and family.

Future research could examine alternative performance related outcomes besides safety performance. For example, Frone et al. (1997) found workfamily conflict to be negatively related to job performance. Other outcomes of economic consequence should be considered as well (i.e. turnover intentions, absenteeism, and supervisor rating). 
In conclusion, the point of this study was to examine the effects of workfamily conflict on safety performance and to assess safety climate's role as a moderator in this relationship. The results suggest that although family-to-work conflict did not have a direct effect on safety performance, it plays an important predictive role in predicting workplace cognitive failure. Workplace cognitive failure in turn significantly predicts safety performance. It is apparent that organizations should consider the role of employees' family when preventing negative safety occurrences. Workplace cognitive failure may be an important predictor of safety behaviors, and future research should explore further antecedents to workplace cognitive failure. 


\section{References}

Allen, T. D. (2001). Family-supportive work environments: The role of organizational perceptions. Journal of Vocational Behavior, 58, 414-435.

Barling, J., MacEwen, K. E., Kelloway, E. K., \& Higginbottom, S. F. (1994). Predictors and outcomes of elder-care based interrole conflict. Psychology and Aging, 9, 391-397.

Barnett, R. C., Marshall, N. L., Raudenbush, S. W., \& Brennan, R. T. (1993). Gender and the relationship between job experiences and psychological distress: A study of dual-earner couples. Journal of Personality and Social Psychology, 65, 794-806.

Baron, R. M., \& Kenny, D. A. (1986). The moderator-mediator variable distinction in social-psychological research: Conceptual, strategic, and statistical considerations. Journal of Personality and Social Psychology, 51, 1173-1182.

Behson, S. J. (2002). Coping with family-to-work conflict: The role of informal work accommodations to family. Journal of Occupational Health Psychology, 7, 324341.

Bianchi, S. M., \& Raley, S. (2005). Time allocation in working families. In S. M. Bianchi., L. M. Casper \& R. B. King (Eds.), Work, family, health \& well-being (pp. 21-42). Mahwah, NJ: Lawrence Erlbaum Associates, Inc.

Bond, J. T., Thompson, C., Galisnsky, E. \& Prottas, D. (2003). Highlights of the national study of the changing workforce. New York, NY: Families and Work Institute. 
Borman, W. C., \& Motowidlo, S. J. (1993). Expanding the criterion domain to include elements of contextual performance. In N. Schmitt, W. C. Borman, \& Associates (Eds.). Personnel selection in organizations (pp. 71-98). San Francisco: Jossey-Bass.

Broadbent, D. E., Cooper, P. F., Fitzgerald, P., \& Parkes, K. R. (1982). The cognitive failures questionnaire (CFQ) and its correlates. British Journal of Clinical Psychology, 21, 1-16.

Brown, R. L., \& Holmes, H. (1986). The use of a factor-analytic procedure for assessing the validity of an employee safety climate model. Accident Analysis and Prevention, 18, 445-470.

Bureau of Labor Statistics (BLS) (2004). United States Department of Labor. Retrieved May 18, 2006, from, http://stats.bls.gov/

Burke, R. J. (1988). Some antecedents and consequences of work-family conflict. Journal of Social Behavior and Personality, 3, 287-302.

Burke, R. J. (1994). Stressful events, work-family conflict, coping, psychological burnout, and well-being among police officers. Psychological Reports, 75, 787 800.

Burke, M. J., Sarpy, S. A., Tesluk, P. E., \& Smith-Crowe, K. (2002). General safety performance: A test of a grounded theoretical model. Personnel Psychology, 55, 429-457.

Chen, P. Y, Rosencrance, J., \& Hammer, L. B. (2006). Construction safety \& work family balance: A challenge and unexplored frontier. Paper presented at the the 
National Occupational Research Agenda (NORA) Symposium, Washington, D.C.

Clarke, S. (2006). The relationship between safety climate and safety performance: A meta-analytic review. Journal of Occupational Health Psychology, 11, 315-327.

Cohen, C. (1980). Aftereffects of stress on human performance and social behavior: A review of research and theory. Psychological Bulletin, 88, 82-108.

Cooke, R. A., \& Rousseau, D. M. (1984). Stress and strain from family roles and work-role expectations. Journal of Applied Psychology, 69, 252-260.

Cooper, M. D., \& Phillips, R. A. (2004). Exploratory analysis of the safety climate and safety behavior relationship. Journal of Safety Research, 35, 497-512.

Cullen, J. C., \& Hammer, L. B. (2007). Developing and testing a theoretical model linking work-family conflict to employee safety. Journal of Occupational Health Psychology, 12, 266-278.

Dedobbeleer, N., \& Beland, F. (1991). A safety climate measure for construction sites. Journal of Safety Research, 22, 97-103.

Dembe, A. E. (2001). The social consequences of occupational injuries and illnesses. American Journal of Industrial Medicine, 40, 403-417.

Duxbury, L. E., \& Higgins, C. A. (1991). Gender differences in work-family conflict. Journal of Applied Psychology, 76, 60-74.

Eby, L. T., Casper, W. J., Lockwood, A. Bordeaux, C., \& Brinley, A. (2005). Work and family research in IO/OB: Content analysis and review of the literature (1980-2002). Journal of Vocational Behavior, 66, 124-197. 
Fried, Y., Ben-David, H. A., Tiegs, R. B., Avital, N., \& Yeverechyahu, U. (1998). The interactive effect of role conflict and role ambiguity on job performance. Journal of Occupational \& Organizational Psychology, 71, 19-28.

Frone, M. R., Russell, M., \& Cooper, M. L. (1991). Relationship of work and family stressors to psychological distress: The independent moderating influence of social support, mastery, active coping, and self-focused attention. Journal of Social Behavior \& Personality, 6, 227-250.

Frone, M. R., Russell, M., \& Cooper, M. L. (1992). Antecedents and outcomes of work-family conflict: Testing a model of the work-family interface. Journal of Applied Psychology, 77, 65-78.

Frone, M. R., Russell, M., \& Cooper, M. L. (1993). Relationship of work-family conflict, gender, and alcohol expectancies to alcohol use/abuse. Journal of Organizational Behavior, 14, 545-558.

Frone, M. R., Yardley, J. K., \& Markel, K. S. (1997). Developing and testing an integrative model of the work-family interface. Journal of Vocational Behavior, $50,145-167$.

Gibeau, J. L., \& Anastas, J. W. (1989). Breadwinners and caregivers: Interviews with working women. Journal of Gerontological Social Work, 14, 19-40.

Gillen, M., Baltz, D., Gassel, M., Kirsch, L., \& Vaccaro, D. (2002). Perceived safety climate, job demands, and coworker support among union and nonunion injured construction workers. Journal of Safety Research, 33, 33-51. 
Glass, J. L., \& Estes, S. B. (1997). The family responsive workplace. Annual Review of Sociology, 23, 289-313.

Goff, S. J., Mount, M. K., \& Jamison, R. L. (1990). Employer supported child care, work/family conflict, and absenteeism: A field study. Personnel Psychology, 43, 793-809.

Golden, T. D., Veiga, J. F., \& Simsek, Z. (2006). Telecommuting's differential impact on work-family conflict: Is there no place like home? Journal of Applied Psychology, 91, 1340-1350.

Good, L. K., Sisler, G. F., \& Gentry, J. W. (1988). Antecedents of turnover intentions among retail management personnel. Journal of Retailing, 64, 295-314.

Greenhaus, J. H., \& Beutell, N. J. (1985). Sources of conflict between work and family roles. Academy of Management Review, 10, 76-88.

Greenhaus, J. H., Parasuraman, S., Granrose, C. S., Rabinowitz, S., \& Mossholder, K. W. (1989). Sources of work-family conflict among two-career couples. Journal of Vocational Behavior, 34, 133-153.

Griffin, M. A., \& Neal, A. (2000). Perceptions of safety at work: A framework for linking safety climate to safety performance, knowledge, and motivation. Journal of Occupational Health Psychology, 5, 347-358.

Goff, S. J., Mount, M. K., \& Jamison, R. L. (1990). Employer supported child care, work/family conflict, and absenteeism: A field study. Personnel Psychology, 43, 793-809. 
Gutek, B. A., Searle, S., \& Klepa, L. (1991). Rational versus gender role explanations for work-family conflict. Journal of Applied Psychology, 7, 560-568.

Hammer, L., Allen, E., \& Grigsby, T. (1997). Work-family conflict in dual-earner couples: Within-individual and crossover effects of work and family. Journal of Vocational Behavior, 50, 185-203.

Hammer, L. B., Bauer, T. N., \& Grandey, A. (2003). Effects of spouses' and own work-family conflict on withdrawal behaviors. Journal of Business and Psychology, 17, 419-436.

Hammer, L. B., Colton, C. L., Caubet, S. L., \& Brockwood, K. J. (2002). The unbalanced life: Work and family conflict. In J. C. Thomas \& M. Hersen (Eds.), Handbook of mental health in the workplace (pp. 83-101). London: Sage.

Hammer, L. B., Cullen, J. C., Neal, M. B., Sinclair, R. R., \& Shafiro, M. V. (2005). The longitudinal effects of work-family conflict and positive spillover on depressive symptoms among dual-earner couples. Journal of Occupational Health Psychology, 2, 138-154.

Hammer, L. B., Kossek, E. E., Alexander, S. A., \& Daniels, R. J. (2006, May). Identifying family-supportive supervisory behaviors for work and family. Paper presented at the $21^{\text {st }}$ annual meeting of the Society for Industrial and Organizational Psychology, Dallas, TX.

Hobfoll, S. E. (1989). Conservation of resources: A new attempt at conceptualizing stress. American Psychologist, 44, 513-524. 
Hobfoll, S. E., \& Shirom, A. (2001). Conservation of resources: Applications to stress and management in the workplace. In R. T. Golembiewski (Ed.), Handbook of organizational behavior (pp. 57-80). New York: Marcel Dekker.

Hofmann, D. A., Morgeson, F. P., \& Gerras, S. J. (2003). Climate as a moderator of the relationship between leader-member exchange and content specific citizenship: Safety climate as an exemplar. Journal of Applied Psychology, 88, $170-178$.

Hofmann, D. A., \& Stetzer, A. (1996). A cross-level investigation of factors influencing unsafe behaviors and accidents. Personnel Psychology, 49, 307-339.

Huang, R., Ho, M., Smith, G. S., \& Chen, P. Y. (2006). Safety climate and selfreported injury: Assessing the mediating role of employee safety control. Accident Analysis and Prevention, 38, 425-433.

Karasek, Jr., R. A. (1979). Job demands, job decision latitude, and mental strain: Implications for job redesign. Administrative Science Quarterly, 24, 285-307.

Kinnunen, U., \& Mauno, S. (1998). Antecedents and outcomes work-family conflict among employed women and men in Finland. Human Relations, 51, 157-177.

Kopelman, R. E., Greenhaus, J. H., \& Connolly, T. F. (1983). A model of work, family, and interrole conflict: A construct validation study. Organizational Behavior and Human Decision Processes, 32, 198-215.

Kossek, E. E., \& Nichol, V. (1992). The effects of on-site child care on employee attitudes and performance. Personnel Psychology, 45, 485- 509.

Kossek, E. E., \& Ozeki, C. (1998).Work-family conflict, policies, and the job-life 
satisfaction relationship: A review and directions for organizational behaviorhuman resources research. Journal of Applied Psychology, 83, 139-149.

Krause, N., \& Lund, T. (2004). Returning to work after occupational injury. In J. Barling, \& M. R. Frone (Eds.), The psychology of workplace safety, (pp. 265295). Washington, DC: American Psychological Association.

Larson, G. E., Alderton, D. L., Neideffer, M., \& Underhill, E. (1997). Further evidence on dimensionality and correlates of the Cognitive Failures Questionnaire. British Journal of Psychology, 88, 29-38.

Lazarus, R. S. (1966). Psychological stress and the coping process. New York: McGraw Hill.

Liao, H., Arvey, R. D., Butler, R. J., \& Nutting, S. M. (2001). Correlates of work injury frequency and duration among firefighters. Journal of Occupational Health Psychology, 6, 229-242.

Loscocco, K. A. (1997). Work-family linkages among self-employed women and men. Journal of Vocational Behavior, 50, 204-226.

Loughlin, C., \& Frone, M. R. (2004). Young workers' occupational safety. In J. Barling, \& M. R. Frone (Eds.), The psychology of workplace safety, (pp. 107126). Washington, DC: American Psychological Association.

MacEwen, K. E., \& Barling, J. (1994). Daily consequences of work interference with family and family interference with work. Work and Stress, 8, 244-254.

Martin, M. (1983). Cognitive failure: Everyday and laboratory performance. Bulletin of Psychonomic Society, 21, 97-100. 
Major, V. S., Klein, K. J., \& Ehrhart, M. G. (2002). Work time, work interference with family, and psychological distress. Journal of Applied Psychology, 87, 427-436.

National Safety Council (2003). Report on Injuries in America: Deaths and injuries in the workplace, home and community, and on roads and highways. Retrieved May 18, 2006, from, http://www.nsc.org/library/report_injury_usa.htm

Neal, M. B., Chapman, N. J., Ingersoll-Dayton, B., \& Emlen, A. C. (1993). Balancing work and caregiving for children, adults, and elders. Newbury Park, CA: Sage.

Neal, A., \& Griffin, M. A. (2004). Safety climate and safety at work. In J. Barling, \& M. R. Frone (Eds.), The psychology of workplace safety, (p. 15-34). Washington, DC: American Psychological Association.

Neal, A., Griffin, M. A., \& Hart, P. M. (2000). The impact of organizational climate on safety climate and individual behavior. Safety Science, 34, 99-109.

Netemeyer, R. C., Boles, J. S., \& McMurrian R. (1996). Development and validation of work-family conflict and family-work conflict scales. Journal of Applied Psychology, 81, 400-410.

O'Driscoll, M. P., Poelmans, S., Spector, P. E., Kalliath, T., Allen, T. D., Cooper, C. L., \& Sanchez, J. I. (2003). Family-responsive interventions, perceived organizational and supervisor support, work-family conflict, and psychological strain. International Journal of Stress Management, 10, 326-344. 
Parasuraman, S., Greenhaus, J. H., \& Granrose, C. S. (1992). Role stressors, social support, and well-being among two-career couples. Journal of Organizational Behavior, 13, 339-356.

Probst, T. M., \& Brubaker, T. L. (2001). The effects of job insecurity on employee safety outcomes: Cross-sectional and longitudinal explorations, Journal of Applied Psychology, 6, 139-159.

Richardsen, A. M., Burke, R. J., \& Mikkelsen, A. (1999). Job pressures, organizational support, and health among Norwegian women managers. International Journal of Stress Management, 6, 167-177.

Siu, O., Phillips, D. R., \& Leung, T. (2004). Safety climate and safety performance among construction workers in Hong Kong: The role of psychological strains as mediators. Accident Analysis and Prevention, 36, 359-366.

Smith, G. S., Huang, Y., Ho, M., \& Chen, P. Y. (2006). The relationship between safety climate and injury rates across industries: The need to adjust for injury hazards. Accident Analysis and Prevention, 38, 556-562.

Stephens, M. A. P., Franks, M. M., \& Atienza, A. A. (1997). Where two roles intersect: Spillover between parent care and employment. Psychology and Aging, 12, 30-37.

Thomas, L. T., \& Ganster, D. C. (1995). Impact of family-supportive work variables on work-family conflict and strain: A control perspective. Journal of Applied Psychology, 80, 6-15. 
Thompson, C. A., Beauvais, L. L., \& Lyness, K. S. (1999). When work-family benefits are not enough: The influence of work-family culture on benefit utilization, organizational attachment, and work-family conflict. Journal of Vocational Behavior, 54, 392-415.

Thompson, C. A., Thomas, C. C., \& Maier, M. (1992). Work-family conflict and the bottom line: Reassessing corporate policies and initiatives. In U. Sekaran \& F. T. Leong (Eds.), Womanpower: Managing in times of demographic turbulence (pp. 59-84). Newbury Park, CA: Sage.

US Census Bureau (2001). Statistical Abstract of the United States: $2001\left(121^{\text {st }}\right.$ ed.). Washington, DC: US Census Bureau.

Varonen, U., \& Mattila, M. (2000). The safety climate and its relationship to safety practices, safety of the work environment and occupational accidents in eight wood-processing companies. Accident Analysis and Prevention, 32, 761-769.

Wallace, J. C., \& Chen, G. (2005). Development and validation of a work-specific measure of cognitive failure: Implications for occupational safety. Journal of Occupational and Organizational Psychology, 78, 615-632.

Wallace, J. C., Popp, E., \& Mondore, S. (2006). Safety climate as a mediator between foundation climates and occupational accidents: A group-level investigation. Journal of Applied Psychology, 91, 681-688.

Wallace, J. C., \& Vodanovich, S. J. (2003a). Workplace safety performance: Conscientiousness, cognitive failure, and their interaction. Journal of Occupational Health Psychology, 8, 316-327. 
Wallace, J. C., \& Vodanovich, S. J. (2003b). Can accidents and industrial mishaps be predicted? Further investigation into the relationship between cognitive failure and reports of accidents. Journal of Business and Psychology, 17, 503-514.

Zohar, D. (1980). Safety climate in industrial organizations: Theoretical and applied implications. Journal of Applied Psychology, 12, 78-85.

Zohar, D. (2000). A group-level model of safety climate: Testing the effect of group climate on microaccidents in manufacturing jobs. Journal of Applied Psychology, 85, 587-596.

Zohar, D. (2003a). Safety climate: Conceptual and measurement issues. In J. C. Quick \& L. Tetrick (Eds.), Handbook of occupational health psychology (pp. 123-142). Washington, DC: APA.

Zohar, D. (2003b). The influence of leadership and climate on Occupational Health and Safety. In D. A. Hofmann, \& L. E. Tetrick (Eds.), Health and safety in organizations, (pp. 201-230). San Francisco, CA: Jossey-Bass. 
Appendix A

Focus Group Process

\section{Portland Water Bureau Focus Groups \\ August 16, 2006}

Have two copies of informed consent, one to read, one to sign and return to us at each place at the table for participants to review as soon as they arrive. Also have short questionnaire at their place to complete.-collect these ASAP prior to beginning Bring pencils or pens for participants

Background and Ground Rules (7:10-7:15)

-Introduce self and notetaker and thank them for coming

-Purpose: to hear about workers thoughts on how the organization handles workers' needs to manage work and family responsibilities; we are using the word family very broadly, as even single people have family responsibilities

-Our Role: mostly to listen and facilitate discussion

-We would like to hear from everyone so please be polite and listen to others and share your views

-We have a number of questions to get through in within the next 45 minutes so we may need to move the group along so we can get to all of them

-Everything said in this group must remain confidential. Please be respectful of each others' privacy and do not repeat anything that is said in this room to anyone else.

-We will be tape recording, so please take turns, talk one at a time, and do not have side conversations as it will make interpretations of the tape difficult.

Note Taker: 1) TURN TAPE RECORDERS ON; 2) DRAW MAP OF TABLEWHO IS SITTING WHERE AND MARK WITH 1, 2, 3, 4 ...and gender of each participant on the map TO BE USED WHEN TAKING NOTES; 3) WHEN TAKING NOTES LIST THE NUMBER OF THE PERSON WHO IS TALKING AND AS MUCH OF WHAT THEY SAY AS POSSIBLE. AFTERWARDS, FILL IN ANY BLANKS YOU CAN REMEMBER. 
Appendix B

Informed Consent Cover Letter-Focus Group

Dear Research Participant,

You are invited to be part of a research project in conjunction with researchers at Portland State University that examines attitudes and perceptions towards safety and work and family issues. The study will involve sharing your opinions in one 45 minute focus group with other workers (or managers) from your company. Your participation is very valuable to us as the results of this study may help increase knowledge that may help others manage safety and work and family demands in the future.

Your participation is voluntary and choosing not to participate will have no effect on your employment, because whether or not you participate will be kept strictly confidential. You may discontinue participation in this study at any time. If you choose to participate and feel uncomfortable answering some of the questions, you may skip them. At no point of time will we share your individual results with anyone. The results that will be shared with your company will describe findings from the employees as a group and so your individual responses cannot be identified.

While there is a risk that some of the people who attend the focus group may share this information with others outside of the group, all group members are asked to keep all information learned in the focus group session completely private and confidential. By signing this form, you agree to keep confidential the information shared during this focus group session.

If you have any questions, you may contact the researchers, Dr. Leslie Hammer (503-725-3971). They will offer to answer any questions about the content or/and procedures of this study. Your responses will be kept completely confidential. Also, none of the information you provide will be shared with either your coworkers or your administration. Please keep this letter for your records.

If you have any concerns about the subject rights, please contact the Chair of the Human Subjects Research Review Committee, Office of Research and Sponsored Projects, 111 Cramer Hall, Portland State University, Portland, Oregon, 97202, (503) 725-4288.

I have read and understand what it means to participate in this study. 
Appendix C

Focus Group Demographics

\section{Demographics}

1. Your age:

2. Your gender: Male Female

3. Marital status: (please check one)

Married for years

Living together for years Single, never married Widowed Divorced

4. Number of children living at home:

5. Are you caring for any aging relatives? Yes No

6. How many hours a week on average do you work? hours

- If you have a second job, how many hours per week do you work in that job? (Leave blank if you have no second job) 
Appendix D

Focus Group Questions

Focus Group Questions (Workers)

- What are your feelings about the importance of safety at the Water Bureau?

- Do you ever feel that conflicts between your family and work roles have an effect on your safety performance on the job? Why or why not?

- How much of an effect do you feel supervisors have on how safe you are at work? Can you give an example?

- What do you feel motivates you to be safe at work? Why?

- What are some examples of problems that distract you from following safety rules or procedures?

- What do you feel the Water Bureau could do to help you balance your work and family responsibilities? How or why would this help?

\section{Focus Group Questions (Crew Leaders and Supervisors)}

- What are your feelings about the importance of safety at the Water Bureau?

- Do you ever feel that conflicts between your family and work roles have an effect on your safety performance on the job? How about for your employees?

- How much of an effect do you feel you, as a supervisor, have on how safe workers are on the job?

- What do you feel motivates employees to be safe at work? Why?

- What are some examples of problems that distract employees from following safety rules or procedures?

- What do you feel the Water Bureau could do to help employees balance your work and family responsibilities? How or why would this help? 


\section{Appendix E}

\section{Safety Fair Flyer}
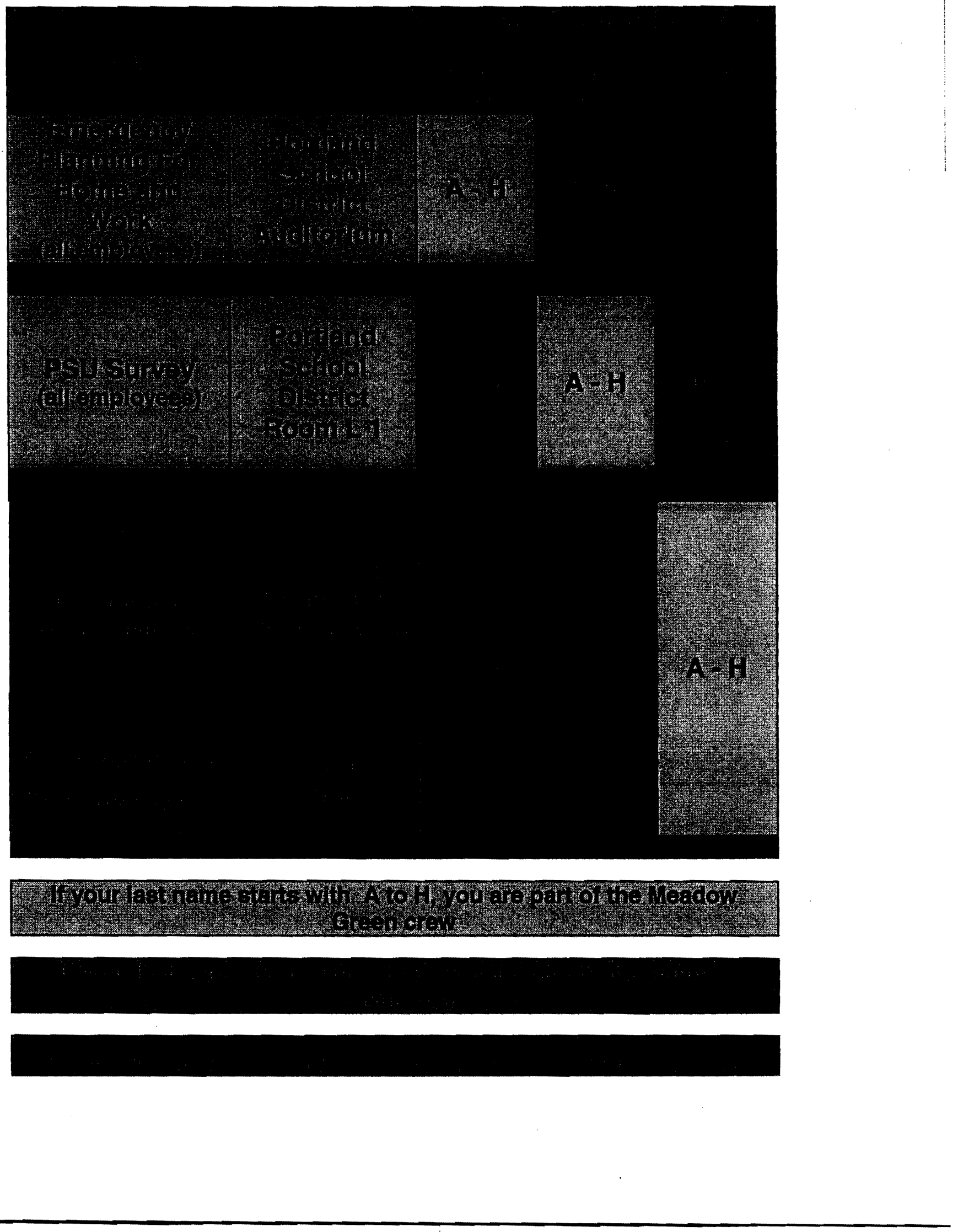


\author{
Appendix F \\ Informed Consent Cover Letter-Survey
}

Dear Research Participant,

You are invited to be part of a research project in conjunction with researchers at Portland State University that examines work and family issues, as well as workplace safety. The study will involve sharing your opinions and experiences on a questionnaire. Your participation is very valuable to us as the results of this study may help increase knowledge that may help others manage safety demands and work and family demands in the future.

Your participation is voluntary and choosing not to participate will have no effect on your employment, because it is strictly confidential. You may discontinue participation in this study at any time. If you choose to participate and feel uncomfortable answering some of the questions, you may skip them. At no point of time will we share your individual results with anyone. The results that will be shared with your company will describe findings from the employees as a group and so your individual responses cannot be identified.

If you have any questions, you may contact the researchers, Dr. Leslie Hammer (503-725-3971). They will offer to answer any questions about the content or/and procedures of this study. Your responses will be kept completely confidential.

Also, none of the information you provide will be shared with either your coworkers or your administration. Please keep this letter for your records.

If you have any concerns about the subject rights, please contact the Chair of the Human Subjects Research Review Committee, Office of Research and Sponsored Projects, 111 Cramer Hall, Portland State University, Portland, Oregon, 97202, (503) $725-4288$.

I have read and understand what it means to participate in this study. 


\section{Appendix G}

Survey with delineated scales

\section{Affective Positive Spillover}

\begin{tabular}{|c|c|c|c|c|c|}
\hline $\begin{array}{l}\text { When things are going well at work, my } \\
\text { outlook regarding my family life is improved. }\end{array}$ & 1 & 2 & 3 & 4 & 5 \\
\hline $\begin{array}{l}\text { Being in a positive mood at work helps me } \\
\text { to be in a positive mood at home. }\end{array}$ & 1 & 2 & 3 & 4 & 5 \\
\hline $\begin{array}{l}\text { Being happy at work improves my spirits at } \\
\text { home. }\end{array}$ & 1 & 2 & 3 & 4 & 5 \\
\hline $\begin{array}{l}\text { Having a good day at work allows me to be } \\
\text { optimistic with my family. }\end{array}$ & 1 & 2 & 3 & 4 & 5 \\
\hline $\begin{array}{l}\text { When things are going well in my family, my } \\
\text { outlook regarding my job is improved. }\end{array}$ & 1 & 2 & 3 & 4 & 5 \\
\hline $\begin{array}{l}\text { Being in a positive mood at home helps me } \\
\text { to be in a positive mood at work. }\end{array}$ & 1 & 2 & 3 & 4 & 5 \\
\hline $\begin{array}{l}\text { Being happy at home improves my spirits at } \\
\text { work. }\end{array}$ & 1 & 2 & 3 & 4 & 5 \\
\hline $\begin{array}{l}\text { Having a good day with my family allows me } \\
\text { to be optimistic at work. }\end{array}$ & 1 & 2 & 3 & 4 & 5 \\
\hline
\end{tabular}

Safety Climate

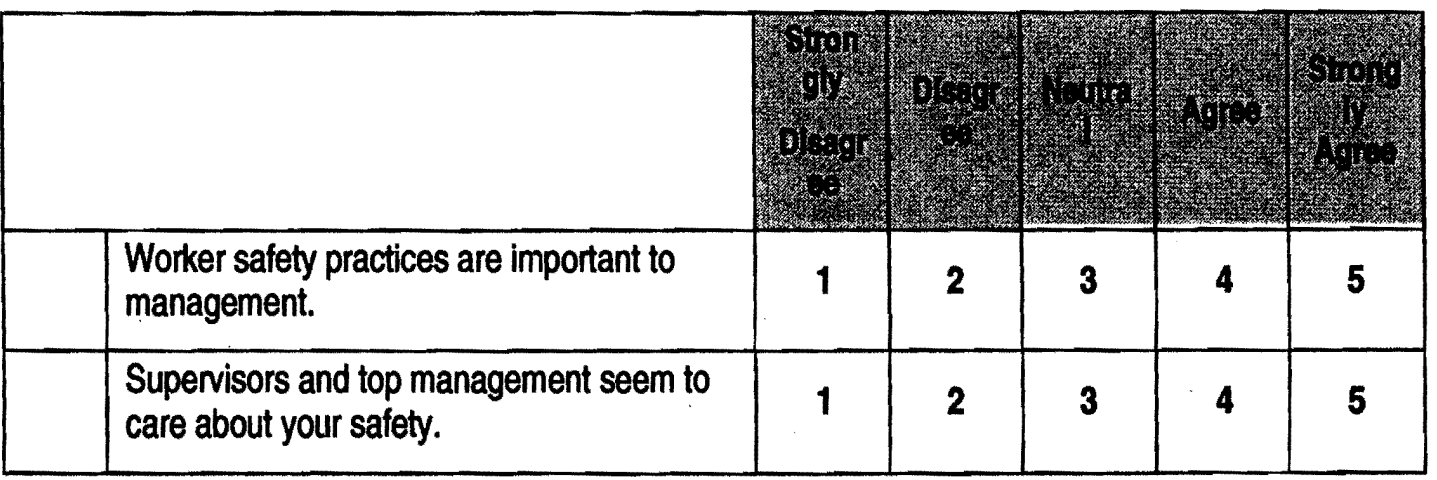




\begin{tabular}{|l|l|c|c|c|}
\hline \multicolumn{2}{|l|}{} & & & \\
\hline
\end{tabular}

\section{Perceived Safety Sensitivity}

\begin{tabular}{|c|c|c|c|c|c|}
\hline & $\begin{array}{l}\text { stroy } \\
67 \\
0 \%\end{array}$ & & (18) & 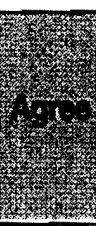 & ing \\
\hline Being safe is a key dimension of my job. & 1 & 2 & 3 & 4 & 5 \\
\hline $\begin{array}{l}\text { Impaired performance in my job could } \\
\text { create a danger or a safety hazard for } \\
\text { me, my co-workers, or the public. }\end{array}$ & 1 & 2 & 3 & 4 & 5 \\
\hline $\begin{array}{l}\text { Not following safety procedures could } \\
\text { create danger or a safety hazard for me, } \\
\text { my coworkers, or the public. }\end{array}$ & 1 & 2 & 3 & 4 & 5 \\
\hline
\end{tabular}


Negative Experiences

\begin{tabular}{|c|c|c|c|c|c|}
\hline $\begin{array}{l}\text { I have experienced a possibly life- } \\
\text { threatening work incident. }\end{array}$ & 1 & 2 & 3 & 4 & 5 \\
\hline $\begin{array}{l}\text { I have worked with a supervisor who } \\
\text { often used unsafe work procedures. }\end{array}$ & 1 & 2 & 3 & 4 & 5 \\
\hline $\begin{array}{l}\text { I have been pressured to use unsafe } \\
\text { work procedures when doing a job. }\end{array}$ & 1 & 2 & 3 & 4 & 5 \\
\hline $\begin{array}{l}\text { I have seen other people have accidents } \\
\text { at work due to unsafe work procedures. }\end{array}$ & 1 & 2 & 3 & 4 & 5 \\
\hline $\begin{array}{l}\text { I have had an accident at work due to } \\
\text { unsafe work procedures. }\end{array}$ & 1 & 2 & 3 & 4 & 5 \\
\hline
\end{tabular}

Safety Motivation

\begin{tabular}{|c|c|c|c|c|c|}
\hline & siriol & $x^{0}$ & (2) & Nitu & shong \\
\hline $\begin{array}{l}\text { I feel that it is worthwhile to be involved in } \\
\text { the development of safe work } \\
\text { procedures. }\end{array}$ & 1 & 2 & 3 & 4 & 5 \\
\hline $\begin{array}{l}\text { I believe that it is important to promote a } \\
\text { safety program. }\end{array}$ & 1 & 2 & 3 & 4 & 5 \\
\hline $\begin{array}{l}\text { I feel that it is important to encourage } \\
\text { others to use safe practices. }\end{array}$ & 1 & 2 & 3 & 4 & 5 \\
\hline $\begin{array}{l}\text { I believe that it is worthwhile to put extra } \\
\text { effort into maintaining safety. }\end{array}$ & 1 & 2 & 3 & 4 & 5 \\
\hline $\begin{array}{l}\text { I feel that it is worthwhile to volunteer for } \\
\text { safety-related tasks. }\end{array}$ & 1 & 2 & 3 & 4 & 5 \\
\hline $\begin{array}{l}\text { I believe that it is important to help my } \\
\text { coworkers in unsafe or hazardous } \\
\text { conditions. }\end{array}$ & 1 & 2 & 3 & 4 & 5 \\
\hline $\begin{array}{l}\text { I feel that adhering to safety procedures } \\
\text { is worthwhile. }\end{array}$ & 1 & 2 & 3 & 4 & 5 \\
\hline
\end{tabular}




\begin{tabular}{|c|c|c|c|c|c|}
\hline $\begin{array}{l}\text { I believe that it is important to always use } \\
\text { safe/standard work procedures. }\end{array}$ & 1 & 2 & 3 & 4 & 5 \\
\hline $\begin{array}{l}\text { I believe that it is important to consistently } \\
\text { use the correct personal protective } \\
\text { equipment. }\end{array}$ & 1 & 2 & 3 & 4 & 5 \\
\hline $\begin{array}{l}\text { I feel that it is worthwhile to use my } \\
\text { personal protective equipment in the } \\
\text { defined areas. }\end{array}$ & 1 & 2 & 3 & 4 & 5 \\
\hline $\begin{array}{l}\text { I feel that adhering to safe procedures is } \\
\text { important in my job. }\end{array}$ & 1 & 2 & 3 & 4 & 5 \\
\hline
\end{tabular}

Safety Performance

\begin{tabular}{|c|c|c|c|c|c|}
\hline & 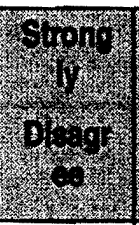 & bist & ingting & 4 & 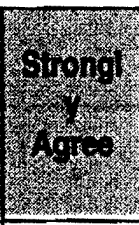 \\
\hline $\begin{array}{l}\text { I promote the safety program within the } \\
\text { organization. }\end{array}$ & 1 & 2 & 3 & 4 & 5 \\
\hline $\begin{array}{l}\text { I put in extra effort to improve the safety } \\
\text { of the workplace. }\end{array}$ & 1 & 2 & 3 & 4 & 5 \\
\hline $\begin{array}{l}\text { Ihelp my coworkers when they are } \\
\text { working under risky or hazardous } \\
\text { conditions. }\end{array}$ & 1 & 2 & 3 & 4 & 5 \\
\hline $\begin{array}{l}\text { I voluntarily carry out tasks or activities } \\
\text { that help to improve workplace safety. }\end{array}$ & 1 & 2 & 3 & 4 & 5 \\
\hline I carry out my work in a safe manner. & 1 & 2 & 3 & 4 & 5 \\
\hline $\begin{array}{l}\text { I use all the necessary safety equipment } \\
\text { to do my job. }\end{array}$ & 1 & 2 & 3 & 4 & 5 \\
\hline $\begin{array}{l}\text { I use the correct safety procedures for } \\
\text { carrying out my job. }\end{array}$ & 1 & 2 & 3 & 4 & 5 \\
\hline $\begin{array}{l}\text { I ensure the highest levels of safety when } \\
\text { I carry out my job. }\end{array}$ & 1 & 2 & 3 & 4 & 5 \\
\hline
\end{tabular}


Safety Climate

\begin{tabular}{|c|c|c|c|c|c|}
\hline $\begin{array}{l}\text { Worker safety practices are important to } \\
\text { management. }\end{array}$ & 1 & 2 & 3 & 4 & 5 \\
\hline $\begin{array}{l}\text { Supervisors and top management seem to } \\
\text { care about your safety. }\end{array}$ & 1 & 2 & 3 & 4 & 5 \\
\hline $\begin{array}{l}\text { Your team leader emphasizes safe practices } \\
\text { on the job. }\end{array}$ & 1 & 2 & 3 & 4 & 5 \\
\hline $\begin{array}{l}\text { Instructions on the safety policies and/or } \\
\text { safety requirements of the company are } \\
\text { provided to employees. }\end{array}$ & 1 & 2 & 3 & 4 & 5 \\
\hline $\begin{array}{l}\text { Your work team's safety meetings are } \\
\text { helpful. }\end{array}$ & 1 & 2 & 3 & 4 & 5 \\
\hline $\begin{array}{l}\text { Proper equipment is available to do your job } \\
\text { safely. }\end{array}$ & 1 & 2 & 3 & 4 & 5 \\
\hline You have control over safety on the job. & 1 & 2 & 3 & 4 & 5 \\
\hline Taking risks is not part of your job. & 1 & 2 & 3 & 4 & 5 \\
\hline $\begin{array}{l}\text { A member of your team will NOT be involved } \\
\text { in an accident in the next 12-month period. }\end{array}$ & 1 & 2 & 3 & 4 & 5 \\
\hline
\end{tabular}

Safety Motivation

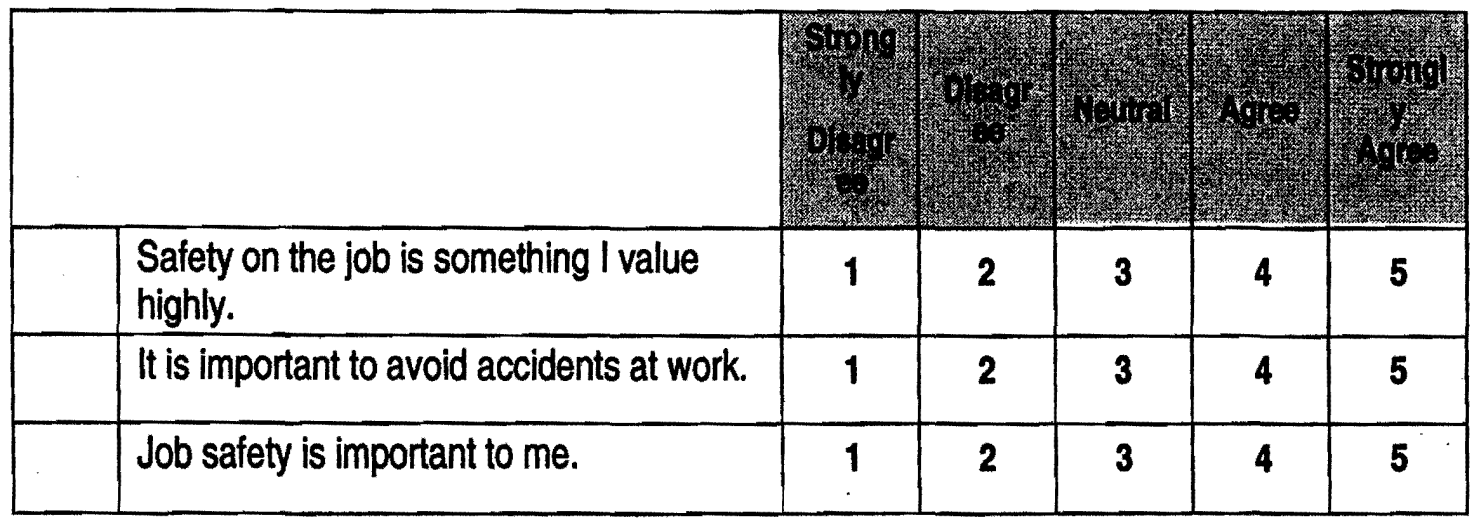




\begin{tabular}{|c|c|c|c|c|c|}
\hline Safety is an important work goal. & 1 & 2 & 3 & 4 & 5 \\
\hline $\begin{array}{l}\text { If I perform all necessary safety } \\
\text { procedures, it will lead to a safe work } \\
\text { environment. }\end{array}$ & 1 & 2 & 3 & 4 & 5 \\
\hline $\begin{array}{l}\text { If I stick to the safety rules, I can avoid } \\
\text { accidents. }\end{array}$ & 1 & 2 & 3 & .4 & 5 \\
\hline $\begin{array}{l}\text { How accurately I perform given safety } \\
\text { procedures will affect whether my } \\
\text { workplace will be safe. }\end{array}$ & 1 & 2 & 3 & 4 & 5 \\
\hline $\begin{array}{l}\text { I can create a safe work environment if I } \\
\text { carry out safety procedures. }\end{array}$ & 1 & 2 & 3 & 4 & 5 \\
\hline $\begin{array}{l}\text { The more safety procedures I perform, } \\
\text { the more likely I am to avoid accidents. }\end{array}$ & 1 & 2 & 3 & 4 & 5 \\
\hline $\begin{array}{l}\text { I can perform the safety procedures if I } \\
\text { try. }\end{array}$ & 1 & 2 & 3 & 4 & 5 \\
\hline $\begin{array}{l}\text { In my work setting, I can actually perform } \\
\text { the suggested safety procedures. }\end{array}$ & 1 & 2 & 3 & 4 & 5 \\
\hline $\begin{array}{l}\text { If I put in the effort, I am able to engage in } \\
\text { safe behaviors at work. }\end{array}$ & 1 & 2 & 3 & 4 & 5 \\
\hline $\begin{array}{l}\text { If I put forth effort, I am able to comply } \\
\text { with safety procedures. }\end{array}$ & 1 & 2 & 3 & 4 & 5 \\
\hline
\end{tabular}

\section{Workplace Cognitive Failure Scale}

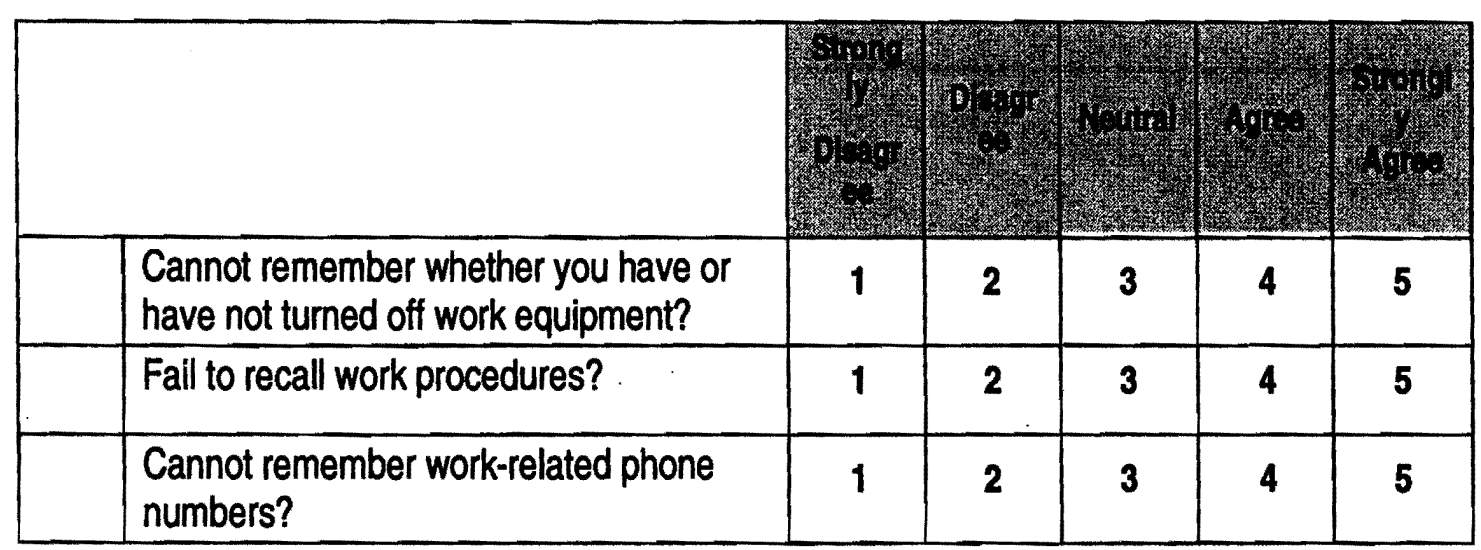




\begin{tabular}{|c|c|c|c|c|c|}
\hline $\begin{array}{l}\text { Cannot remember what materials are } \\
\text { required to complete a particular task? }\end{array}$ & 1 & 2 & 3 & 4 & 5 \\
\hline $\begin{array}{l}\text { Forget where you have put something } \\
\text { you use in your job (e.g. tools)? }\end{array}$ & 1 & 2 & 3 & 4 & 5 \\
\hline $\begin{array}{l}\text { Fail to notice postings or notices on the } \\
\text { facilities bulletin board(s) or e-mail } \\
\text { system? }\end{array}$ & 1 & 2 & 3 & 4 & 5 \\
\hline Do not fully listen to instruction? & 1 & 2 & 3 & 4 & 5 \\
\hline $\begin{array}{l}\text { Day-dream when you ought to be } \\
\text { listening to somebody? }\end{array}$ & 1 & 2 & 3 & 4 & 5 \\
\hline $\begin{array}{l}\text { Do not focus your full attention on work } \\
\text { activities? }\end{array}$ & 1 & 2 & 3 & 4 & 5 \\
\hline Are easily distracted by coworkers? & 1 & 2 & 3 & 4 & 5 \\
\hline Accidentally drop objects or things? & 1 & 2 & 3 & 4 & 5 \\
\hline $\begin{array}{l}\text { Throw away something you mean to keep } \\
\text { (e.g. memos, tools)? }\end{array}$ & 1 & 2 & 3 & 4 & 5 \\
\hline $\begin{array}{l}\text { Say things to others that you did not } \\
\text { mean to say? }\end{array}$ & 1 & 2 & 3 & 4 & 5 \\
\hline $\begin{array}{l}\text { Unintentionally press control switches on } \\
\text { machines? }\end{array}$ & 1 & 2 & 3 & 4 & 5 \\
\hline $\begin{array}{l}\text { Accidentally started or stopped the wrong } \\
\text { machine? }\end{array}$ & 1 & 2 & 3 & 4 & 5 \\
\hline
\end{tabular}

\section{Work-family Conflict}

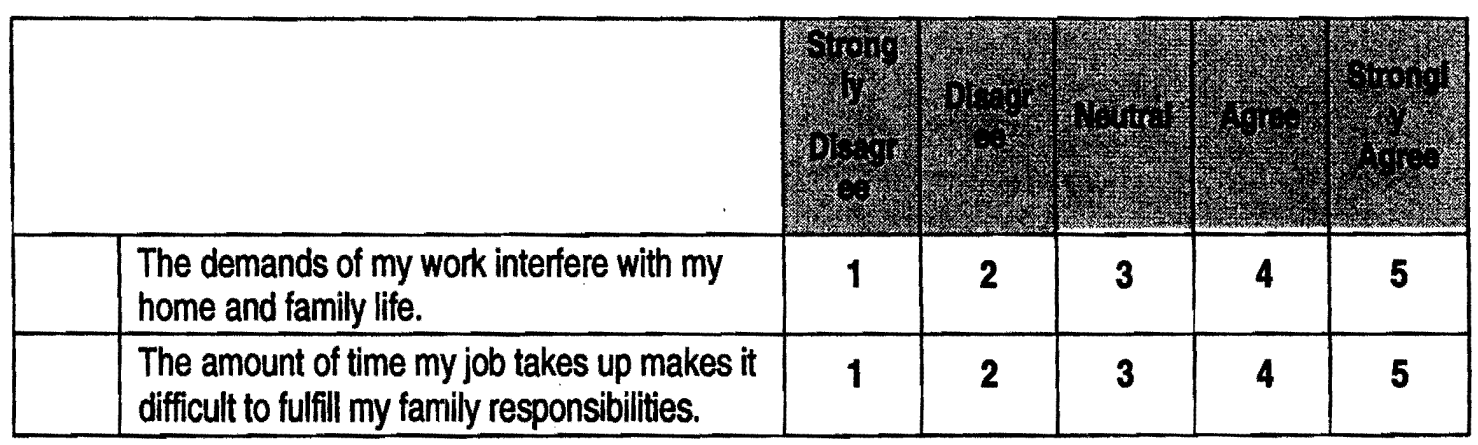




\begin{tabular}{|c|c|c|c|c|c|}
\hline $\begin{array}{l}\text { Things I want to do at home do not get done } \\
\text { because of the demands my job puts on me. }\end{array}$ & 1 & 2 & 3 & 4 & 5 \\
\hline $\begin{array}{l}\text { My job produces strain that makes it difficult } \\
\text { to fulfill family duties. }\end{array}$ & 1 & 2 & 3 & 4 & 5 \\
\hline $\begin{array}{l}\text { Due to my work-related duties, I have to } \\
\text { make changes to my plans for family } \\
\text { activities. }\end{array}$ & 1 & 2 & 3 & 4 & 5 \\
\hline $\begin{array}{l}\text { The demands of my family or spouse/partner } \\
\text { interfere with work-related activities. }\end{array}$ & 1 & 2 & 3 & 4 & 5 \\
\hline $\begin{array}{l}\text { I have to put off doing things at work because } \\
\text { of demands on my time at home. }\end{array}$ & 1 & 2 & 3 & 4 & 5 \\
\hline $\begin{array}{l}\text { Things I want to do at work don't get done } \\
\text { because of the demands of my family or } \\
\text { spouse/partner. }\end{array}$ & 1 & 2 & 3 & 4 & 5 \\
\hline $\begin{array}{l}\text { My home life interferes with my } \\
\text { responsibilities at work, such as getting to } \\
\text { work on time, accomplishing daily tasks, and } \\
\text { working overtime. }\end{array}$ & 1 & 2 & 3 & 4 & 5 \\
\hline
\end{tabular}

Personality Mini-Markers (conscientiousness, agreeableness, neuroticism)

\begin{tabular}{|c|c|c|c|c|c|c|}
\hline 1 & 2 & 3 & 4 & 5 & 6 & 7 \\
\hline $\begin{array}{c}\text { extremely } \\
\text { inaccurate }\end{array}$ & inaccurate & $\begin{array}{c}\text { somewhat } \\
\text { inaccurate }\end{array}$ & $\begin{array}{c}\text { neither } \\
\text { inaccurate } \\
\text { /accurate }\end{array}$ & $\begin{array}{c}\text { somewhat } \\
\text { accurate }\end{array}$ & accurate & $\begin{array}{c}\text { extremely } \\
\text { accurate }\end{array}$ \\
\hline
\end{tabular}

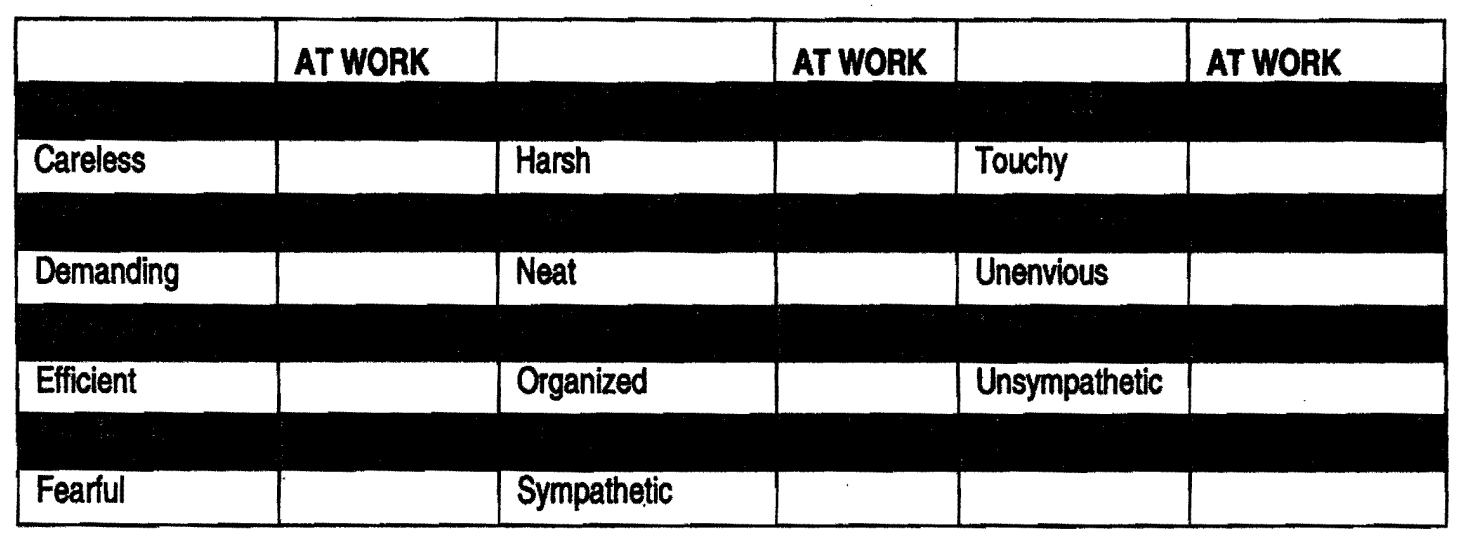




\section{Injuries}

About how many times in the past year have you been injured at your job and needed to get even very minor medical attention? times.

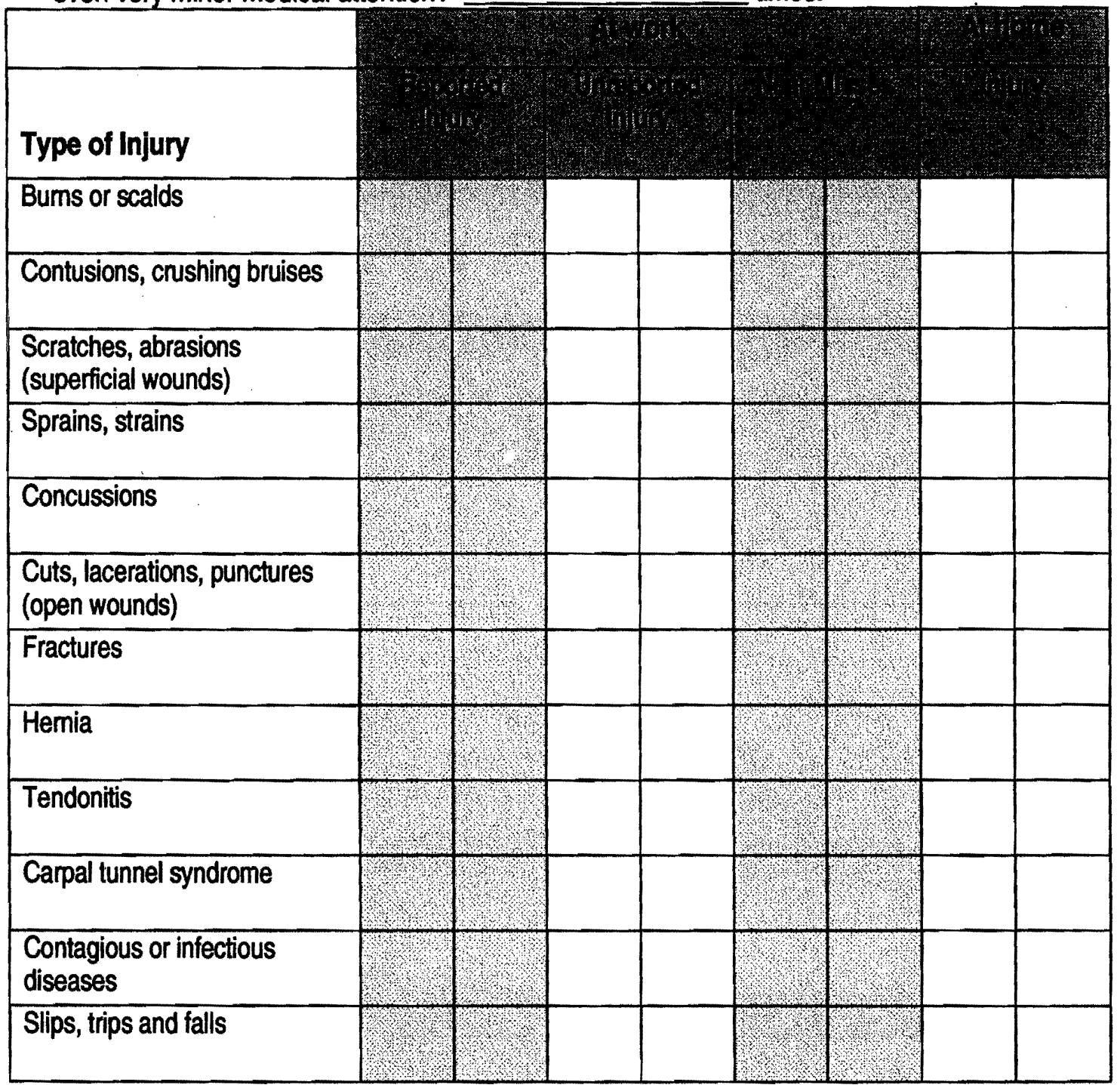




\section{Demographics}

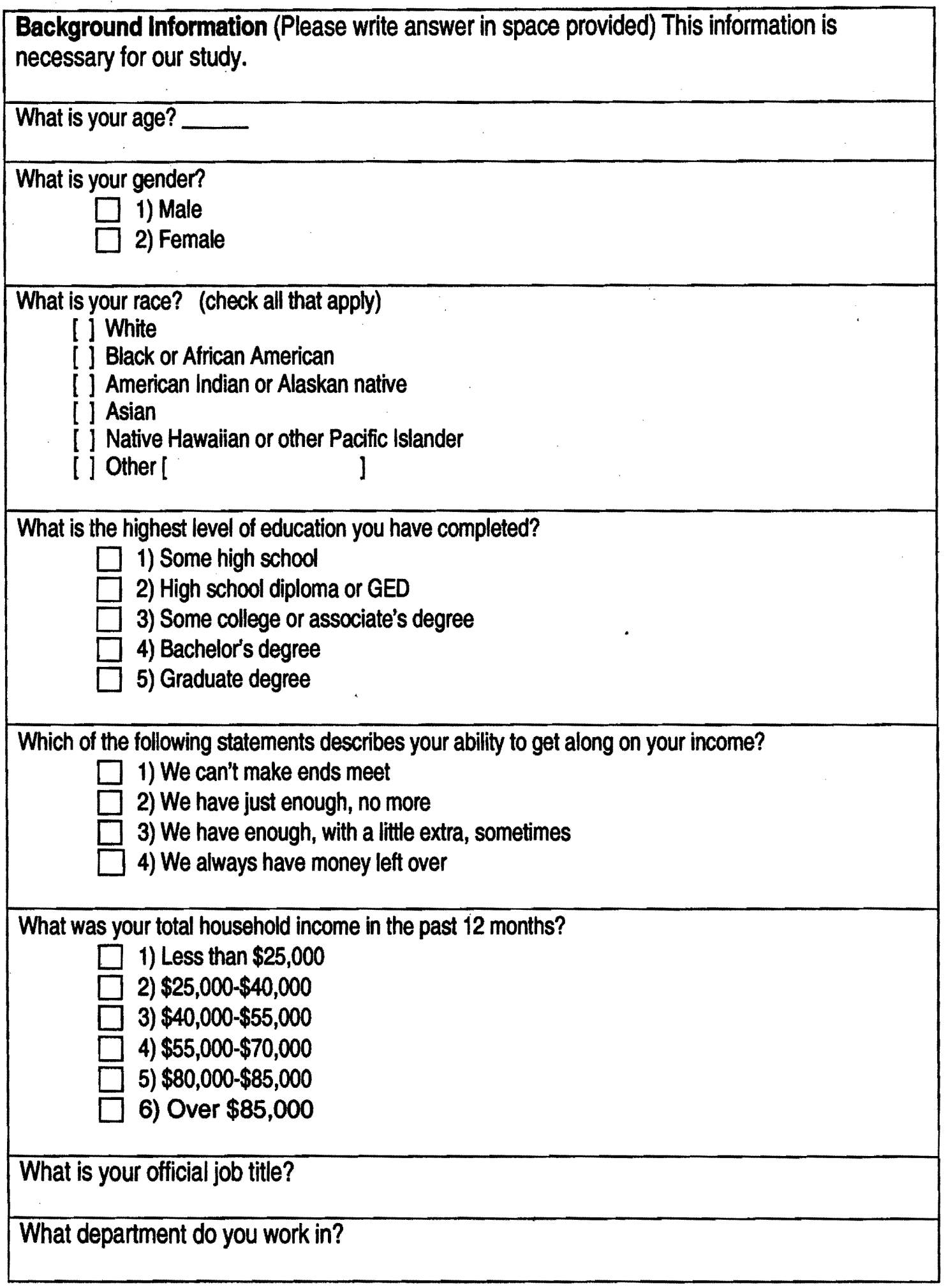




\begin{tabular}{|c|}
\hline $\begin{array}{l}\text { Which best matches your role at work? } \\
\square \text { 1) Non-supervisory employee } \\
\square \text { 2) Crew leader } \\
\square \text { 3) Supervisor }\end{array}$ \\
\hline How many years of total full-time work experience do you have? \\
\hline How many years of total part-time work experience do you have? \\
\hline How long have you worked for this company? ___ Years ___ Months \\
\hline How long have you worked on this work site? \\
\hline How many hours do you currently work per week? __ hours \\
\hline $\begin{array}{l}\text { What is your relationship status? } \\
\qquad \begin{array}{l}\square \text { 1) Married } \\
\text { 2) Divorced or separated } \\
\square \text { 3) Widowed } \\
\square \text { 4) Living as married } \\
\square \text { 5) Never married }\end{array}\end{array}$ \\
\hline How many kids do you have under age $18 ?$ \\
\hline How many hours of childcare per week do you use for your youngest child? ___ hours \\
\hline Are you providing care for elderly parents? $\quad \square$ Yes $\quad \square$ No \\
\hline If yes, how many parents do you care for? \\
\hline $\begin{array}{l}\text { Average hours per week a parent was helped by you and/or your spouse or partner: } \\
\text { hours }\end{array}$ \\
\hline
\end{tabular}

Are there any other thoughts or opinions you would like to share about safety at the Water Bureau? 
Table 1

Means and Standard Deviations for Demographics

\begin{tabular}{|c|c|c|c|}
\hline & $N$ & Mean & SD \\
\hline & 134 & & \\
\hline Age in Years & 128 & 39.14 & 11.38 \\
\hline $\begin{array}{l}\text { Years of Full-time } \\
\text { work experience }\end{array}$ & 123 & 18.65 & 11.59 \\
\hline $\begin{array}{l}\text { Years of Part-time } \\
\text { work experience }\end{array}$ & 100 & 3.73 & 4.73 \\
\hline $\begin{array}{l}\text { Years worked for } \\
\text { Water Bureau }\end{array}$ & 127 & 8.04 & 8.6 \\
\hline $\begin{array}{l}\text { Years worked on } \\
\text { particular work } \\
\text { site }\end{array}$ & 120 & 6.46 & 7.74 \\
\hline $\begin{array}{l}\text { Hours worked per } \\
\text { week }\end{array}$ & 125 & 42.15 & 5.97 \\
\hline $\begin{array}{l}\text { Number of } \\
\text { children }\end{array}$ & 128 & .75 & 1 \\
\hline $\begin{array}{l}\text { Hours of childcare } \\
\text { per week }\end{array}$ & 120 & 4.3 & 11.65 \\
\hline $\begin{array}{l}\text { Number of } \\
\text { parents cared for }\end{array}$ & 124 & .23 & .56 \\
\hline $\begin{array}{l}\text { Hours spent } \\
\text { caring for parents } \\
\text { per week }\end{array}$ & 125 & 2.42 & 7.06 \\
\hline
\end{tabular}


Table 2

Frequencies for Categorical Demographics

\begin{tabular}{|c|c|c|}
\hline Variable & Categories & Percentage \\
\hline \multirow[t]{2}{*}{ Gender } & Male & 82.1 \\
\hline & Female & 14.2 \\
\hline \multirow[t]{7}{*}{$\underline{\text { Race }}$} & White & 71.6 \\
\hline & Black or African American & 3.7 \\
\hline & American Indian/ Alaskan native & 3.0 \\
\hline & Asian & 5.2 \\
\hline & $\begin{array}{l}\text { Native Hawaiian/Pacific } \\
\text { Islander }\end{array}$ & 2.2 \\
\hline & Hispanic & 6 \\
\hline & Other & 4.5 \\
\hline \multirow[t]{5}{*}{ Education } & Some high school & 4.5 \\
\hline & High school diploma/ GED & 29.9 \\
\hline & Some college/ Associate's degree & 44.8 \\
\hline & Bachelor's degree & 14.2 \\
\hline & Graduate degree & 3.0 \\
\hline \multirow{3}{*}{$\begin{array}{l}\text { Ability to get } \\
\text { along on income }\end{array}$} & We can't make ends meet & 5.2 \\
\hline & We have just enough, no more & 21.6 \\
\hline & $\begin{array}{l}\text { We have enough, with a little } \\
\text { extra sometimes }\end{array}$ & 47 \\
\hline
\end{tabular}




\begin{tabular}{|c|c|c|}
\hline Variable & Categories & Percentage \\
\hline & We always have money left over & 22.4 \\
\hline \multirow{6}{*}{$\begin{array}{l}\text { Total household } \\
\text { income }\end{array}$} & Less than $\$ 25,000$ & 7.5 \\
\hline & $\$ 25,000$ to $\$ 40,000$ & 11.9 \\
\hline & $\$ 40,000$ to $\$ 55,000$ & 20.9 \\
\hline & $\$ 55,000$ to $\$ 70,000$ & 30.6 \\
\hline & $\$ 70,000$ to $\$ 85,000$ & 9.0 \\
\hline & Over $\$ 85,000$ & 15.7 \\
\hline \multirow[t]{3}{*}{ Work role } & Non-supervisory employee & 72.4 \\
\hline & Crew leader & 18.7 \\
\hline & Supervisor & 3.7 \\
\hline \multirow{5}{*}{$\begin{array}{l}\text { Relationship } \\
\text { status }\end{array}$} & Married & 46.3 \\
\hline & Divorced or Separated & 14.2 \\
\hline & Widowed & .7 \\
\hline & Living as married & 9.7 \\
\hline & Never married & 25.4 \\
\hline
\end{tabular}


Table 3

Intercorrelations between Study Variables

Variables

1

2

3

4

5

6

Mean SD

1.Gender

$2.29 \quad .82$

2. Family-to-

Work

Conflict

$-.02 \quad(.89)$

$.88 \quad .33$

3. Workplace

Cognitive

Failure

$-.04 \quad .43^{* *} \quad(.91)$

$2.15 \quad .60$

4. Safety

$\begin{array}{lllll}\text { Participation } & .01 & -.09 & -.31 * * & (.79)\end{array}$

$3.83 \quad .65$

5. Safety

Compliance

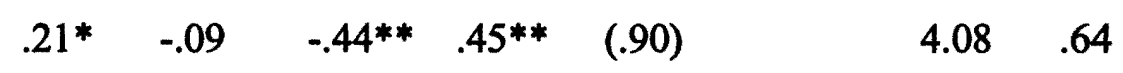

6. Safety

$\begin{array}{lllllllll}\text { Climate } & .16 & -.13 & -.19 * & .12 & .45^{* *} & (.80) & 3.82 & .56\end{array}$

Note. ${ }^{*} p<.05,{ }^{* *} p<.01$. Scale reliabilities are shown in parentheses. Gender: men $=0$, women $=1$; Variables 2-6 were measured using a 5-point Likert scale, $1=$ strongly disagree and $5=$ strongly agree. 
Table 4

Summary of Regression Analysis for Testing Hypothesis 4a: Workplace cognitive failure as a mediator in the relationship between family-to-work conflict and safety participation.

\begin{tabular}{llll}
\hline Variable & $\Delta R^{2}$ & $F$ Change & $\beta$ \\
\hline
\end{tabular}

Hierarchical Regression

Step 1: Safety Participation

Gender

Family-to-Work Conflict

$-.06$

Step 2: Workplace Cognitive Failure

Gender

$-.03$

Family-to-Work Conflict

Step 3: Safety Participation

Gender

Workplace Cognitive Failure
.00 .48

$-.00$

$-.30 * *$

Step 4: Safety Participation

.09

11.46

Family-to-Work Conflict

.07

Workplace Cognitive Failure 
Table 5

Summary of Regression Analysis for Testing Hypothesis 4b: The mediated effect of workplace cognitive failure on the relationship between family-to-work conflict and safety compliance.

\begin{tabular}{llll}
\hline Variable & $\Delta R^{2}$ & $F$ Change & $\beta$ \\
\hline
\end{tabular}

Hierarchical Regression

Step 1: Safety Participation

Gender

Family-to-Work Conflict

$-.07$

Step 2: Workplace Cognitive Failure

$-.03$

Gender

Family-to-Work Conflict

Step 3: Safety Compliance

.00

.65

Gender

Workplace Cognitive Failure

Step 4: Safety Compliance

.18

28.88

Family-to-Work Conflict

$-.12$

Workplace Cognitive Failure $-.47 * *$

Note. $N=134 .{ }^{*} p<.05,{ }^{* *} p<.01$. IV $=$ Family-to-Work Conflict; Mediator $=$ Workplace Cognitive Failure; DV = Safety Compliance. 
Table 6

Summary of Hierarchical Regression Analysis for Testing Hypothesis 5a: The effect of family-to-work conflict on safety participation depends on safety climate.

\begin{tabular}{|c|c|c|c|}
\hline Variable & $\Delta R^{2}$ & $F$ Change & $B$ \\
\hline Step 1: & .00 & .00 & \\
\hline Gender & & & .01 \\
\hline Step 2: & .10 & 6.40 & \\
\hline Workplace Cognitive Failure & & & $-.30 * *$ \\
\hline Safety Climate & & & .05 \\
\hline Step 3: & .01 & 1.77 & \\
\hline $\begin{array}{l}\text { Workplace Cognitive Failure * } \\
\text { Safety Climate }\end{array}$ & & & .12 \\
\hline
\end{tabular}


Table 7

Summary of Hierarchical Regression Analysis for Testing Hypothesis 5b: The effect . of family-to-work conflict on safety compliance depends on safety climate.

\begin{tabular}{|c|c|c|c|}
\hline Variable & $\Delta R^{2}$ & $F$ Change & $B$ \\
\hline Step 1: & .04 & 5.52 & . \\
\hline Gender & & & .21 \\
\hline Step 2: & .30 & 28.28 & \\
\hline Workplace Cognitive Failure & & & $-.36^{* *}$ \\
\hline Safety Climate & & & $.36^{* *}$ \\
\hline Step 3: & .01 & 1.26 & \\
\hline $\begin{array}{l}\text { Workplace Cognitive Failure * } \\
\text { Safety Climate }\end{array}$ & & & .09 \\
\hline
\end{tabular}


Table 8

Summary of Regression Analysis for Testing Post Hoc Analyses

\begin{tabular}{|c|c|c|}
\hline Variable & $R^{2}$ & $\beta$ \\
\hline Safety Participation & .00 & \\
\hline Gender & & .02 \\
\hline Work-Family Conflict & & .05 \\
\hline Safety Compliance & .05 & \\
\hline Gender & & $.21^{*}$ \\
\hline Work-Family Conflict & & -.09 \\
\hline Safety Participation & .02 & \\
\hline Gender & . & .03 \\
\hline Work-to-Family Conflict & & .12 \\
\hline Family-to-Work Conflict & & -.11 \\
\hline Safety Compliance & .06 & \\
\hline Gender & & .20 \\
\hline Work-to-Family Conflict & & -.80 \\
\hline Family-to-Work Conflict & & -.04 \\
\hline Safety Participation & .02 & \\
\hline Gender & & -.09 \\
\hline Family-to-Work Conflict & & -1.0 \\
\hline Safety Compliance & .06 & \\
\hline Gender & & .18 \\
\hline Family-to-Work Conflict & & -.15 \\
\hline
\end{tabular}


Table 9

Summary of Regression Analysis for Testing Post Hoc Analyses: Workplace cognitive failure as a mediator in the relationship between family-to-work conflict and the valence component of safety motivation.

\begin{tabular}{|c|c|c|c|}
\hline Variable & $\Delta R^{2}$ & $F$ Change & $\beta$ \\
\hline \multicolumn{4}{|l|}{ Hierarchical Regression } \\
\hline \multicolumn{4}{|l|}{ Step 1: Safety Motivation Valence } \\
\hline Family-to-Work Conflict & & & $-.22^{*}$ \\
\hline \multicolumn{4}{|l|}{ Family-to-Work Conflict } \\
\hline Step 3: Safety Motivation Valence & .29 & 54.63 & \\
\hline Workplace Cognitive Failure & & & $-.54 * *$ \\
\hline Step 4: Safety Motivation Valence & .24 & 43.68 & \\
\hline \multicolumn{4}{|l|}{ Family-to-Work Conflict } \\
\hline Workplace Cognitive Failure & & & $-.54^{* *}$ \\
\hline
\end{tabular}


Figure 1. Theoretical Framework for the Relationships between Family-to-Work Conflict, Workplace Cognitive Failure, Safety Performance and Safety Climate.

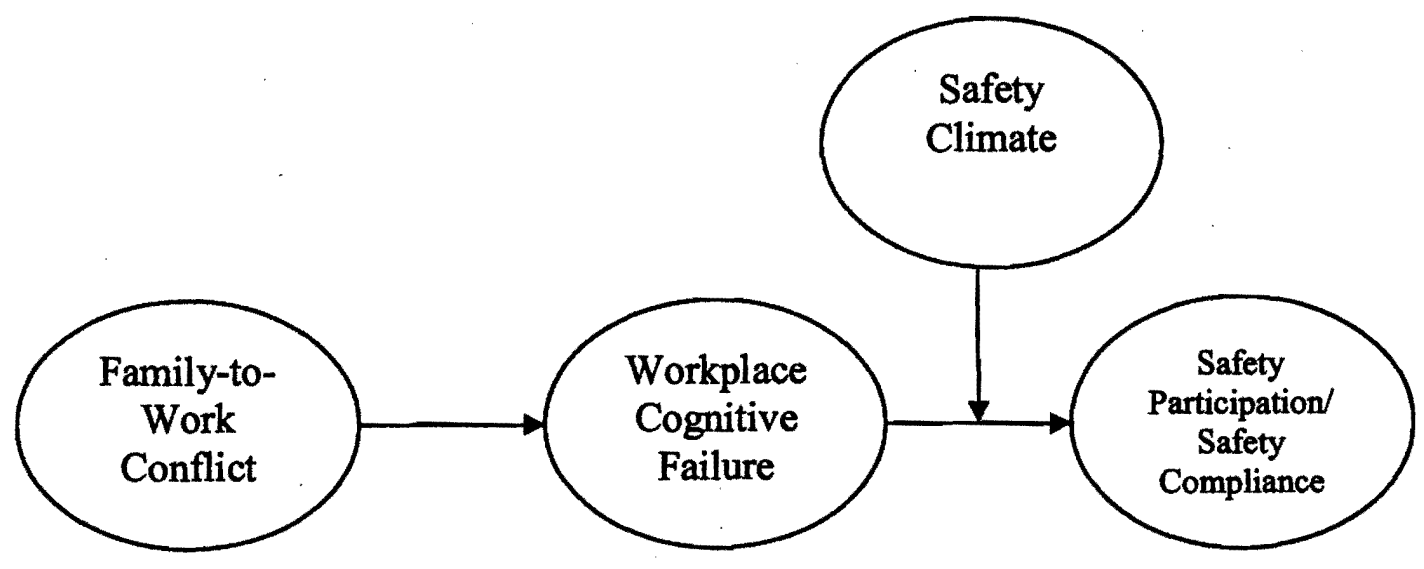

